\title{
Review on Application of Oncolytic Virotherapy of Cancer Cells in Veterinary Medicine
}

\author{
Tamirat Demissie Sultan Abda ${ }^{*}$ \\ Hawassa University, Faculty of Veterinary Medicine
}

\begin{abstract}
Oncolytic virotherapy is using oncolytic viruses (OVs) which selectively infect and kill cancer cells. Oncolytic viruses represent a highly targeted approach to established cancer that brings a multimechanistics approach and an acceptable safety profile to patients with a variety of cancers. A variety number of viruses have been developed as oncolytic virotherapeutics, including Adenovirus, Vaccinia virus, Herpesvirus, Measles, Coxsackie A virus, Newcastle disease virus, and Reovirus. Anticancer viruses can now be engineered to selectively attack cancer cells, spare normal tissue, awaken the host immune system and reverse immunosuppression in the tumor microenvironment. But virotherapy is not a cure on its own. Research suggests that virotherapies will serve to supplement chemotherapy, radiation therapy or immunotherapy. Combinations of OV with cytotoxic agents are feasible and safe, with the potential of transient immune supperssion of the host in order to increase viral access to the tumor and provide time for viral oncolysis to exceed the tumor's replicative potential. Granulocyte macrophage colony stimulating factor as an immune-stimulatory cytokine boosts host immune activity through the infiltration of dendritic cells and CD4+ and CD8+ T cells at tumor sites. Concomitants to human, cancer is the leading cause of death in companion animals such as dogs and cats. The most important challenges for the successful clinical use of OVs in veterinary practice are reduction of viral toxicity, optimization of virus delivery to tumor, and enhancement of viral spread throughout the tumor mass. The multifactorial, interplay can be determined by the complex interactions between the tumor and its microenvironment, the virus, and the host immune response. Yet, there is promise that OVs will soon be a new, powerful treatment option for veterinary patients with cancer. Hence, sound understanding of the biology of OVs and its application in veterinary medicine require.
\end{abstract}

Keywords: Cancer, Combination-therapy, Oncolytic virotherapy, Virus.

DOI: $10.7176 /$ ALST/79-04

Publication date:March $31^{\text {st }} 2020$

\section{INTRODUCTION}

The potential of viruses as anti-cancer agents was first realised in the early twentieth century, although coordinated research efforts did not begin until the 1960s (Alemany, 2013). Oncolytic virotherapy is an emerging anti-cancer treatment modality that uses OVs. One of the most attractive features of the OVs is that they are either naturally occurring or genetically engineered to selectively infect, replicate in and damage tumor cells while leaving normal cells intact (Workenhe and Mossman, 2014; Guo et al., 2008). In the 1920s animal experiments confirmed that viruses were capable of infecting and lysing experimental murine tumors and several studies followed in the 1950s demonstrating potent oncolysis of murine tumors by Newcastle disease virus and Influenza virus (Kelly and Russell, 2007).

A mouse was considered the first animal model to demonstrate full regression through viral oncolysis (Nicholas et al., 2003). Incidence of cancer ranges from 1 to 2 percent in the canine population and currently accounts for about half of the deaths in dogs older than 10 years (Merlo et al., 2008). A number of viruses including adenovirus, reovirus, measles, herpes simplex virus, Newcastle disease virus, and vaccinia have been clinically tested as oncolytic agents (Donnelly et al., 2012). Most current OVs are engineered for tumour selectivity, although there are naturally occurring examples such as reovirus and the senecavirus (Roberts, 2006).

Cancer is one of the most common causes of natural death in dogs in both developed and developing countries. It is among the top deadly diseases in dogs and cats (Merlo et al., 2008). In contrast to the progress of human oncolytic virotherapy, there are very few clinical trials using OVs for canine or feline cancer patients (Patil et al., 2012). The most common forms of cancer in dogs and cats are skin, lymphoma, mammary, bone, connective tissue, and oral cancers (Paoloni and Khanna, 2008; Tang et al., 2010). Oncogenic viruses can establish a chronic infection allowing them to escape from the host's immune-system while producing proteins that control cell death and proliferation. Chronic infection also leads to inflammatory reactions promoting cancer development (McLaughlinDrubin and Munger, 2008).

To potentiate their immunogenic effects, genetic engineering strategies have been used to encode OVs with various cytokines, immunomodulators, and tumor associated antigens (Melcher et al., 2011). Clinical evaluation of adoptive T cell transfer and OVs are currently underway as mono- therapies (Patel and Kratzke, 2013). Viral oncolysis directly destroys tumor cells through either their lytic replication cycle or the expression of endogenous cytotoxic gene products (Chu et al., 2004). To further enhance their oncolytic effects, transgenes encoding pro- 
apoptotic proteins are inserted into OVs to subvert cell death machinery. These proteins include various death inducing ligands such as TNF-related apoptosis inducing ligand (Wohlfahrt et al., 2007; Zhao et al., 2006).

Through transgene insertion, OVs can serve as directed gene delivery vehicles, and thus accommodate a diverse array of therapeutic strategies. Arming OVs with additional weaponry, such as pro-apoptotic genes, tumor suppressors, or genes stimulating antitumor immunity, can enhance their killing capacity. With a broad arsenal, modified OVs have the potential to target a wide spectrum of different cancer types. Moreover, administration of OVs as a monotherapy has demonstrated varying degrees of success in clinical trials (Vacchelli et al., 2013; Buonaguro et al., 2012).

Over an extended period, selective pressure on heterogeneous tumor populations can also lead to therapeutic resistance to OVs via receptor loss or mutation of essential signaling pathways required for viral replication (Moerdyk-Schauwecker et al., 2013). NDv binds cells via the hema gglutinin neuraminidase (HN) protein (Park et al., 2003). PV701 and MTH68/H are live attenuated oncolytic viral strains of NDv, which have the capacity to selectively replicate in and lyse tumor cells and to cause immune-stimulation (Fournier et al., 2012) and become one of the promising new therapeutic approach of oncolytic virotherapy. OVs exhibit selective viral replication in tumors and metastases resulting in the killing of cancer cells and the initiation of tumor-specific immunity (Liu et al., 2007; Chen and Szalay, 2011).

Canine cancers share many features in common with human cancers including histological appearance, tumor genetics, molecular targets and response to conventional therapy (Al-Dissi et al., 2010; Mederle et al., 2010; Amorim et al., 2010). In both species, tumor initiation and progression is influenced by similar factors like age, nutrition, sex and environmental exposure (Hlavaty et al., 2011). One reason for the lack of efficient therapeutic response associated with early conditionally replicative adenoviruses can be the absence of the primary canine adenovirus receptor (CAR) on some cancer cells, as has been reported in gastrointestinal, pancreatic, ovarian, and hormone refractory prostate cancers. Specific strategies to enhance CAR-independent transduction of conditionally replicative adenovirus refractory cancer cell types and improve tumor-specific immunity have utilized modifications to the viral coat to induce better cancer selectivity and provide proinflammatory signals. Adenovirus-35 is a strain that utilizes CD46, rather than CAR, as the primary receptor for initial adsorption and entry (Gaggar et al., 2005; Sirena et al., 2004). This vector demonstrated enhanced selectivity and stronger adenovirus affinity for the targeted cell (Tanaka et al., 2006). Moreover, control mechanisms have been added to adenoviruses to ensure cancer cell specificity, and arming the virus with suicide genes has also been explored to improve therapeutic effects (Liu et al., 2005). Adenoviruses are also being tested as therapeutic agents for canine cancers. Human adenovirus 5 has been shown to productively replicate in canine osteosarcoma and canine mammary carcinoma cells (Ternovoi et al., 2005).

Herpes simplex virus tumor selectivity is enhanced further by gain of function mutations occurring in given oncogenes of the Ras-signaling pathway of transformed cells, whereby tumor cells with augmented Ras activation are significantly more susceptible to oncolytic herpes simplex virus infection than healthy cells with normal Ras signal transduction pathway physic- ology (Pan et al., 2009). Recruitment of innate immune cells associated with direct lysis of tumor cells and priming of adaptive immunity was seen, including an accumulation of activated natural killer cells and immunogenic dendritic cells (Benencia et al., 2005).

Coxsackie virus could also activate neutrophils to release interferon- $\beta$ and antigen-presenting cel ls and to induce cytotoxic T lymphocytes (Jablonska et al., 2010). Coxsackie virus B3 exhibit ed potent tumor cell lysis in a number of non-small cell lung cancer cell lines, even in cancer cells refractory to conventional radiotherapy and molecular targeted therapies (Prestwich et al., 2009). OVs induces oncolytic-mediated tumor regression, insertion of the gene encoding GM-CSF resulted in rejection of distant noninjected A20 tumors in mice, suggesting the vector could induce potent local oncolytic effects and generate systemic antitumor immunity (Liu et al., 2003). Reovirus oncolysis of cancer cells is mediated mainly via the extrinsic apoptosis pathway (Clarke et al., 2007; Smakman et al., 2006). Depending on the tumor cell infected, reovirus induced apoptosis uses different proapoptotic molecules to activate apoptosis. For example, the HeLa cell line requires NF- $\kappa \mathrm{B}$ for apoptosis, while specific ovarian, breast, and lung cancer cell lines activate death receptor pathway of apoptosis (Clarke et al., 2007).

Reovirus, like other oncolytic vectors, is subject to immune recognition and rapid clearance. Use of immune suppressant drugs, such as cyclophosphamide and cyclosporine A, has been shown to potentiate oncolysis and increase reovirus replication in injected tumor tissue with enhanced reovirus-mediated tumor clearance (Qiao et al., 2008). An oncolytic measles virus armed with genes coding for antibodies against inhibitory immune checkpoints has been shown to have improved antitumor activity compared to control virus. It appears to be a synergistic effect between oncolytic measles virus and immune checkpoint inhibitors (Engeland et al., 2014).

Although, a lot of studies have been done over the causes of cancer, there is still the paucity of information regarding to virotherapheutic efficacy and associated factors in animal cancer. Therefore, the objectives of this review are:

* To give the base line overview on oncolytic virotheraphy for cancer cells. 
* To describe the major OVs utilized with various tumor cells.

* To describe the mode of actions, advantages and limitations of some of the viral vectors commonly used for oncolytic virotherpy incompnien animals.

\section{ONCOLYTIC VIROTHERAPY FOR CANCER CELLS IN VETERINARY MEDICINE}

An OVs is a virus that preferentially infects and kills cancer cells. As the infected cancer cells are destroyed by oncolysis, they release new infectious virus particles or virions to help destroy the remaining tumour (Ferguson $e t$ al., 2012; Casjens, 2010). OVs are thought not only to cause direct destruction of the tumour cells, but also to stimulate host anti tumour immune system responses (Melcher et al., 2011; Lichty, 2014). Adenovirus 5 (Ad5) subtype has been extensively used in oncolytic virotherapy as a vector (Ginsberg, 2013).

Herpes simplex virus (HSV) was one of the first viruses to be adapted to attack cancer cells selectively, because it was well understood, easy to manipulate and relatively harmless in its natural state (merely causing cold sores) so likely to pose fewer risks. The herpes simplex virus type 1 (HSV-1) mutant 1716 lacks both copies of the ICP34.5 gene, and as a result is no longer able to replicate in terminally differentiated and non-dividing cells but will infect and cause lysis very efficiently in cancer cells, and this has proved to be an effective tumour targeting strategy (van den Hengel et al., 2013). In a wide range of in vivo cancer models, the HSV1716 virus has induced tumour regression and increased survival times (Allen et al., 2013; Josupeit et al., 2016).

The current trend is to use recombinant strains with decreased pathogenicity and improved antitumor effect. However, naturally occurring oncolytic NDV strains are also observed. The oncolytic potential of NDV strains circulating in wild migratory birds of Russia remains poorly understood. The oncolytic wild-type NDVs from natural reservoirs obtained in 2008-2014 in Russia. They are demonstrate the in vitro ability of NDVs to influence the viability of tumor cells after infection and evaluate in vivo efficiency of NDV strain against non-small cell lung carcinoma (li et al., 2011, Song et al., 2010, Bai et al., 2014, Elankumaran et al., 2010, Zamarin et al., 2009 and An et al., 2016).

Canine lymphoid cell lines and B and T lymphocytes established from dogs with lymphoma have been shown to express CD150 receptors. Attenuated CDV has been tested for oncolytic property in the lymphoma cells and was able to infect and induce apoptosis in these cells (Suter et al., 2005). The molecular mechanisms underlying virus induced carcinogenesis are diverse and complex. In addition to causing direct effects such as induction of genomic instability, DNA damage, and viral oncogene triggered cell transformation (Chen et al., 2014).

\subsection{Mechanisms of Oncolytic Virus-mediated Tumor Ablation 2.1.1 Tumor tropism and oncolysis}

Oncolytic virotheraphy have the ability to establish a niche of continuous viral replication within the tumor, recruit uninfected cells in proximity creating syncytia, infect dividing and non-dividing cells, and be stable in vivo, yet lack chromosomal integration and do not result in major disease (Verheije and Rottier, 2012). OVs, like reovirus (Prestwich et al., 2012), vaccinia virus (Thorne et al., 2008), can induce tumor specific adaptive immune responses and indirectly cause malignant cell death. Adenovirus (Diaconu etal., 2012),Coxsackie B3(Miyamoto et al., 2012)and measles virus (Donnelly et al., 2013), can lead to endoplasmic reticulum stress and cause immunologic cell death a type of cell death that leads to release of danger association molecular patterns, like adenosine triphosphate, calreticulin and high mobility group box-1, which attract immune cells (Kepp et al., 2011).

OVs can also selectively target tumor neovasculature. Vesicular stomatitis virus (VSV) can selectively infect endothelial cells in the tumor microenvironment and cause thrombosis in the tumor vessels (Breitbach et al., 2011). HSV and vaccinia virus can also selectively damage tumor endothelium(Benencia et al., 2005; Breitbach et al., 2013); preferential replication in tumor vessels may be secondary to the dependence on high vascular endothelial growth factor (VEGF) and fibroblast growth factor (FGF) levels for replication in normal endothelium (Breitbach et al., 2013) .

Therefore, instead of relying on receptor specificity, tumor tropism of vesicular stomatitis virus is dependent on the permissiveness of malignant cells to viral infection. VSV belongs to a class of interferon (IFN) sensitive viruses, which preferentially infects tissues exhibiting reduced or absent IFN responsiveness (Krishnamurthy et al., 2006; Stojdl et al., 2003; Noser et al., 2007). Selective retargeting of viruses to tumor cells can also be generated in viruses without innate oncolytic abilities. Adenovirus based vectors are a good demonstration of this approach, since they possess a wide tropism, but a lytic life cycle that can be exploited for oncolytic virotherapy (Kruyt and Curiel, 2002).The pathogenicity and tissue tropism are similar within the subgroups (Wold and Toth, 2013).

Viruses are small passive particles that reach their target cells via either radial cell-to-cell spread or diffusion across concentration gradients in soluble matters, such as blood, and propagate infection. They are higher the number of infectious virions at the tumor territory, the higher the probability of infecting and destroying every single tumor cell (Miller and Russell, 2014; Smith et al., 2014). It is important to investigate how infection of the host normal cells by the OVs can enhance the oncolytic virotherapy. To normal cells, such as liver, that can be 
quickly self regenerated after a trauma or disease, infection of normal cells could be tolerable if such infection is not endemic (that means the infection does not persist forever) and could potentially aid to control tumor growth (Ribacka and Hemminki, 2008).

Measels virus (MV) enters cells through interaction of its H-protein and cellular CD46 (membrane cofactor protein) and signaling lymphocyte activating molecule (Tatsuo et al., 2000). CD46 is overexpressed on tumor cells (Fishelson et al., 2003), MV vaccine affects only cells with a high density of CD46, and therefore, does not affect normal cells (Anderson et al., 2004). MV kills tumor cells by inducing cell-to-cell fusion through F-protein, formation of syncytia and subsequent apoptotic death (Anderson et al., 2004). Several preclinical studies in animal models, including both solid tumors and hematologic malignancies, have evaluated MV through different routes (ITu, IV, IP or intrapleural) and administration schedules (Blechacz et al., 2006).

The enzymes thymidine kinase and ribonucleotide reductase in cells are responsible for DNA synthesis and are only expressed in cells which are actively replicating (Gentry, 1992). These enzymes also exist in the genomes of certain viruses like HSV, vaccinia and allow viral replication inquiescent (non-replicating) cells (Singh et al., 2012), so if they are inactivated by mutation the virus will only be able to replicate in proliferating cells, such as cancer cells. All these models were used to investigate adenoviral targeting on cancer stem-like cells. Resistant cancer stem-like cells constitute a major hurdle in cancer therapy, especially when combating glioblastomas. As such, reovirus, measles vaccine virus, and parvovirus have been successfully targeted to glioblastoma stem-like cells in spheroid models (van den Hengel et al., 2013, Josupeit et al., 2016). Treated animal tumors demonstrate cytopathic effect with syncytia formation followed by apopt- otic cell death of MV-infected tumor cells (Zhang et al., 2012). Canine p53 family proteins have biological activities similar to their human counterparts (Zhang et al., 2009), mutations in conserved domains of p53 appear to play a significant role in mammary carcinogenesis in both humans and dogs (Queiroga et al., 2011).

Oncolytic viruses are distinguished by their property to either inherently or after genetic modifi -cation replicates selectively in cancer cells. These viruses have multiple mechanisms to harm the host cells including direct lysis, induction of apoptosis and autophagy, expression of toxic prot- eins and shutdown of proteinsynthesis. At the end of the replication cycle, cells are destroyed and infective viral progeny is released into remaining tumor tissue. In addition to local amplifying antitumor effect, infective viral particles are able to enter the systemic circulation and infect distant metastasis (Roberts et al., 2006).

\subsubsection{Induction of antitumor immune responses}

To enhance viral distribution and tumor cell killing, irradiation has been successfully combined with an oncolytic adenovirus in glioblastoma spheroids (Lamfers et al., 2007). Lower myxoma-virus-mediated cell killing in spheroids than in adherent cells, because of downregulated Akt kinase in non-adherent cells (Correa et al., 2012). An oncolytic virus destroys tumors either by direct viral lysis of tumor cells(Atherton andLichty, 2013; Gentschev et al., 2012), by the destruction of the tumor vasculature (Gentschev et al., 2012), by induction of host antitumoral immune responses(Gentschev et al., 2013; Fridlender et al., 2009) or most likely, a combination of these mechanisms(Moehler et al., 2005)(Figure 1). An increased infiltration of neutrophils, macrophages and natural killer cells to the tumor site might be involved in the vaccinia virus mediated immune response in different canine cancer xenograft models (Breitbach et al., 2007; Winkler et al., 2004).

The presence of such activated inflammatory cells in the tumor tissue may enhance the antitumoral effect by increasing the phagocytic or cytotoxic activities of these cells (Ferrara et al., 2003; Millanta et al., 2002). In addition, an increase in proinflammatory interferon gamma (IFN-gamma), interleukin-2 (IL-2), interleukin-6 (IL6), tumor necrosis factoralpha (TNF-alpha), interferon gamma-induced protein 10 (IP-10), macrophage inflammatory protein-1 alpha (MIP-1 alpha), macrophage inflammatory protein-1 beta (MIP-1 beta), monocyte chemotactic protein-1 (MCP-1), and monocyte chemotactic protein-3 (MCP-3) was observed in vaccinia virusinfected canine xenografted mice(Patil et al., 2012). 


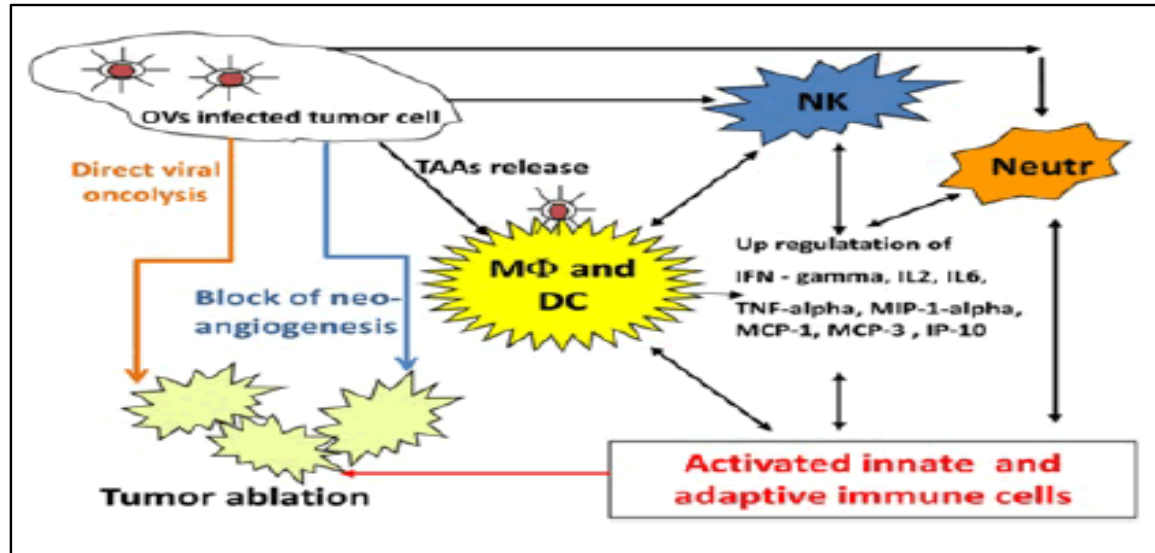

Figure 1: Possible mechanisms of oncolytic virus-mediated tumor ablation.

Many of these proteins stimulate innate immunity mediated by dendritic cells, neutrophils, macrophages and NK cells. OVs naturally prevent neoangiogenesis either by direct infection and destruction of tumor vasculature (Adelfinger et al., 2014) or "vascular normalization" in tumor tissue, as described by Winker and colleagues (Breitbach et al., 2016). IFNs are a group of secreted cytokines; exert pleiotropic effects on important cell functions, including cell prolifera tion and modulation of the immune system (Dunn et al., 2006; Stetson and Medzhitov, 2006).

\subsection{Use of Oncolytic Virotherapy of Cancer in Animals}

\subsubsection{Toxicity of Oncolytic Viruses to Pet Cancer Patients}

Some NDV strains have been developed to elicit potent oncolytic capacity. The MTH-68/H strain showed beneficial effects in patients with advanced cancer (Csatary et al., 2004). This strain exerts direct cytotoxicity in vitro against various tumor cell lines, suggesting that direct cytotoxicity and oncolysis are key factors in the antitumor activity. NDV-induced apoptosis of infected tumor cells is the dominant mode of cytotoxicity, but activation of either the intrinsic or extrinsic apoptotic pathways is cell type dependent (Elankumaran et al., 2006). Overall, onco lytic virus therapy has been well tolerated, with largely minor and expected toxicity, and no evidence of uncontrolled or latent infection, household transmission, or malignant transfor mation (Russell et al., 2012; Cattaneo et al., 2008).

Table 1: Oncolytic viruses tested for cancer therapy.

\begin{tabular}{|c|c|c|}
\hline Virus strain & $\begin{array}{l}\text { Virus } \\
\text { family/Virus type }\end{array}$ & Study/Tumor type/Animal model Ref. \\
\hline $\begin{array}{l}\text { Canine adenovirus type } 2 \\
\text { (CAV2) }\end{array}$ & $\begin{array}{l}\text { Adenoviridae } \\
\text { (double stranded } \\
\text { DNA viruses) }\end{array}$ & $\begin{array}{l}\text { Infection of canine osteosarcoma } \\
\text { cells and osteosarcoma xenografted (Hemminki et al., 2003) } \\
\text { mice }\end{array}$ \\
\hline $\begin{array}{l}\text { Human adenovirus type } 5 \\
\text { (Ad5) }\end{array}$ & Adenoviridae & $\begin{array}{l}\text { Infection of canine osteosarcoma, } \\
\text { melanoma and mammary carcinoma (Ternovoi et al.,2005) } \\
\text { cells }\end{array}$ \\
\hline Ad5, CAV2 & Adenoviridae & $\begin{array}{l}\text { Infection of canine cells and (Le et al., 2006) } \\
\text { osteosarcoma xenografted mice }\end{array}$ \\
\hline CAV2 & Adenoviridae & $\begin{array}{l}\text { Infection of canine osteosarcoma (Smith et al., 2006) } \\
\text { cells and healthy dogs }\end{array}$ \\
\hline CAV2 & Adenoviridae & $\begin{array}{l}\text { Treatment of canine osteosarcoma } \\
\text { xenografts using tumor cells as a (Alcayaga-Miranda } \\
\text { carrier for CAV2 } \\
\text { al., 2010) }\end{array}$ \\
\hline $\begin{array}{l}\text { Ad5-based vector with CD40 } \\
\text { ligand (AdCD40L) }\end{array}$ & Adenoviridae & $\begin{array}{l}\text { Treatment of canine malignant (Westberg et al., 2013; } \\
\text { melanoma patients }\end{array}$ \\
\hline $\begin{array}{l}\text { Ad5-based vector encoding } \\
\text { IL-12 (Ad hsp feline IL-12) }\end{array}$ & Adenoviridae & $\begin{array}{l}\text { Treatment of cats with soft tissue (Siddiqui et al., 2007) } \\
\text { sarcoma }\end{array}$ \\
\hline $\begin{array}{l}\text { Ad5-vector-mediated } \\
\text { gene transfer }\end{array}$ & Adenoviridae & $\begin{array}{l}\text { Treatment of canine osteosarcoma (Kanaya et al., 2011) } \\
\text { xenografts }\end{array}$ \\
\hline Distemper & Paramyxoviridae & Infection of canine lymphoid, (Suter et al., 2005) \\
\hline
\end{tabular}




\begin{tabular}{|c|c|c|}
\hline Virus strain & $\begin{array}{l}\text { Virus } \\
\text { family/Virus type }\end{array}$ & Study/Tumor type/Animal model Ref. \\
\hline$(\mathrm{CDV})$ & $\begin{array}{l}\text { (single stranded } \\
\text { RNA viruses) }\end{array}$ & osteosarcoma and melanoma cells \\
\hline Reovirus & $\begin{array}{l}\text { Reoviridae (double } \\
\text { stranded } \\
\text { viruses) }\end{array}$ & $\begin{array}{l}\text { Infection of canine mast cell tumor } \\
\text { cells (MCT) and treatment of MCT (Hwang et al., 2013) } \\
\text { xenograft mice }\end{array}$ \\
\hline $\begin{array}{l}\text { Vaccinia virus (Lister) strain } \\
\text { (GLV-1h68) }\end{array}$ & $\begin{array}{l}\text { Poxviridae }(\text { double } \\
\text { stranded } \text { DNA } \\
\text { viruses })\end{array}$ & $\begin{array}{l}\text { Treatment of canine mammary } \\
\text { adenoma and carcinoma and soft } 2010 ; 2012) \\
\text { tissue sarcoma xenograft mice }\end{array}$ \\
\hline $\begin{array}{l}\text { Vaccinia virus (Lister) strain } \\
\text { expressing anti-VEGF } \\
\text { antibody (GLV-1h109) }\end{array}$ & Pox & $\begin{array}{l}\text { Treatment of canine soft tissue (Patil et al., 2012) } \\
\text { sarcoma and prostate xenograft mice }\end{array}$ \\
\hline $\begin{array}{l}\text { Vaccinia virus (Lister) strain } \\
\text { (LIVP 6.1.1) }\end{array}$ & Poxviridae & $\begin{array}{l}\text { Treatment of canine soft tissue } \\
\text { sarcoma and prostate xenografted } \\
\text { mice }\end{array}$ \\
\hline $\begin{array}{l}\text { Vaccinia virus (Lister) strain } \\
\text { expressing anti-VEGF } \\
\text { antibody (GLV-5b451) }\end{array}$ & Poxviridae & $\begin{array}{l}\text { Treatment of feline mammary (Adelfinger et al., } \\
\text { carcinoma xenograft mice }\end{array}$ \\
\hline Myxoma virus (MYXV) & Poxviridae & $\begin{array}{l}\text { Infection of different canine tumor (Urbasicet al., 2012) } \\
\text { cells }\end{array}$ \\
\hline Myxoma virus (MYXV) & Poxviridae & Infection of feline carcinoma cells \\
\hline $\begin{array}{l}\text { Canary pox virus expressing } \\
\text { IL2 (ALVAC-fIL2) }\end{array}$ & Poxviridae & $\begin{array}{l}\text { Therapy of cats with feline (Jourdier et al., 2003) } \\
\text { fibrosarcomas }\end{array}$ \\
\hline $\begin{array}{l}\text { Vaccinia virus (Copenhagen) } \\
\text { strain expressing IL2 } \\
\text { (NYVAC-fIL2) }\end{array}$ & Pox & $\begin{array}{l}\text { Therapy of feline fibrosarcoma (Jourdier et al., 2003) } \\
\text { patients }\end{array}$ \\
\hline
\end{tabular}

\subsubsection{Optimization of Onclytic virotheraphy delivery to the Tumor tissue and metastases}

As a result, oncolytic virotherapy may result in incomplete eradication of the primary tumor mass or possibly even promote metastasis of the tumor cells and eventually leading to recurrence of disease. Similar to what is observed in chemotherapy and radiotherapy regimens, malignant cells are also prone to become resistant to oncolytic virotherapy over time. This is presumably linked to the intrinsic nature of cancers to exhibit genomic instability and the propensity for accumulating mutations (Alain et al., 2006; Vitale et al., 2011).

Viral replication was demonstrated via transgene expression of GFP or luciferase. Moreover, they quantified viral DNA in the supernatant. In conclusion, the authors showed replication of the wild-type adenovirus in liver slices, whereas replication of the tumor targeted virus was almost fully restricted to tumor slices and attenuated in liver slices. Mixed slices are containing tumor and healthy liver tissue (Zimmermann et al., 2009). Genetic engineering of oncolytic viruses is supported by the safety data from genetically engineered products like DNA vaccine in dogs and non-human primates (Peruzzi et al., 2010; Pluhar et al., 2010).

Multiple ambiguities exist regarding the optimization of combination strategies. It is unclear when the OV should be administered in regards to other novel agents. For example, administration of checkpoint inhibitors with $\mathrm{OV}$ on the same day or subsequent days in clinical trials or preclinical models has been performed but not been compared in a single study. Real-time evidence of enhanced antitumor immune response generation as well as dynamic imaging for tumor perfusion may be methods that predict the benefit from oncolytic virotherapy. For example, in patients treated with T-VEC who develop minimal increase in $\mathrm{CD}^{8+} \mathrm{T}$ cells from baseline after 6 weeks of therapy, the risk of subsequent disease progression is high (Puzanov et al., 2016).

Canine osteosarcoma cells treated with replication selective canine adenovirus (OCCAV) were used as virus carriers for evading pre-existing neutralizing antibodies against adenovirus. When administered systemically, even in the presence of adenovirus neutralizing antibodies, OCCAV carrier cells showed superior infection of tumors and tumor regression in a xenograft mouse model compared to OCCAV (osteosarcoma cell canine adenovirus) alone (Alcayaga-Miranda et al., 2010). Moreover, the enhanced oncolytic effects were attributed to an increase in the effective local viral dose in the tumor as a con- sequence of the tumor specific delivery of the virus by the cells and the escape of the pre-exist- ing antiviral immunity (Power et al., 2007; Fujiwara et al., 2011).

\subsubsection{Enhancing anti-tumor immunity and/or anti-tumor effects of OVs by virus-integrated genes}

Oncolytic viruses (OVs) have a number of advantages over conventional antitumor agent, because they have their own cancer specificity and better safety margin. They selectively target and replicate in cancer cells, as a host cell; 
thus, OVs survive by lysing cancer cells (Guo et al., 2008). OVs-mediated oncolysis not only leads to tumor regression but also provides important immune responses. Key signals provided by oncolysis to dendritic cells and other antigen-presenting cells (APCs) can then initiate additional potent antitumor immune response (Kaufman et al., 2015). OVs have been recently recognized as an effective treatment for cancer in preclinical models and promising clinical responses in human cancer patients (Russell et al., 2012).

In addition to its oncolytic characteristics, OV can be engineered to express some functional genes. For instance, granulocyte macrophage colony-stimulating factor (GM-CSF) expression in OVs increases tumor cell lysis. GM-CSF is an immune modulator, acts as a paracrine manner on various cells, and recruits circulating neutrophils, monocytes, and lymphocytes to enhance their functions in host defense (Kanerva et al., 2013). As for HCC treatment in clinical trials, adeno- virus and vaccinia virus are mostly used (Downs-Canner et al., 2016; Samson et al., 2016). Oncolytic viruses form a diverse biological group whose members belong to at least 10 different virus families, contain either an RNA or a DNA genome, and vary considerably as regards geno me size, particle complexity, and natural host preferences (Russel et al., 2012).

OVs naturally possess or are engineered to acquire the capacity to selectively infect, replicate in, and destroy tumor cells (oncolysis) while sparing their normal counterparts (Russel et al., 2012; Kelly and Russel, 2007). Multiple factors explain this onco-selectivity altered expression by tumor cells of virus entry receptors and/or intracellular permissiveness factors, rapid tumor cell division and high metabolic activity, deficient antiviral type I interferon responses in tumor cells (Lawler et al., 2016). Furthermore, there is mounting evidence that OV infection of tumor cells induces an immunogenic process, with neo-antigen recognition and establishment of specific antitumor immune responses (Lichty et al., 2014).

Enhanced glioma cell killing has been observed when the virus was applied shortly after tumor cell irradiation, suggesting that this protocol might be translated to cases of non-resectable recurrent glioblastoma (Geletneky et al., 2010). In animal models, local, systemic, or intranasal administration of H-1PV has been found to cause regression of advanced tumors, virus replication being restricted to tumor tissues (Geletneky et al., 2010; Kiprianova et al., 2011). In addition, administration of this modified canine adenovirus to normal dogs showed only moderate virus-associated toxicity and showed therapeutic benefits in the xenograft model in killed canine osteosarcoma cells in cell culture (Carter et al., 2005).

In addition, armed oncolytic viruses can also prevent neoangiogenesis, leading to cancer cell necrosis. Vascular endothelial growth factor (VEGF) is a protein that plays a key role in tumor angiogenesis (Hicklin and Ellis, 2005). Another approach that has been used to enhance viral potency has been to arm a conditionally replicative adenovirus with transgenes that promote anti tumor activity through other mechanisms, including use of antiangiogenesis and immuno stim ulatory genes (Jin et al., 2005; Seth et al., 2006). Evasion of the immune system has been accom plished by the use of chemical polymers or poly-ethylene glycol to coat conditionally replicative adeno viruses, which in turn increased local virus delivery to tumor sites (Doronin et al., 2009).

Other approaches have tried to enhance the intrinsic cytolytic properties of NDV via increased expression of native viral proapoptotic proteins (example, F-protein), inhibition of innate immune responses for enhancement of viral replication and cell-to-cell spread, tumor-associated antigens, and immunostimulatory cytokines (example, GM-CSF, IL-2, and tumor necrosis factor- $\alpha$ ) (Zamarin et al., 2012). The importance of the immune response with oncolytic NDV vectors has been highlighted in murine tumor models (Fournier et al., 2012). Therapeutic activity can be seen with only a small dose of injected NDV, suggesting that therapeutic responses are not comp letely dependent on the oncolytic activity of the virus (Bian et al., 2006).

\subsubsection{Successful combination therapy is context-dependent}

Recently, the combination of oncolytic virotherapy with chemotherapy has shown that use of these two therapies with very distinct antitumor mechanisms may also lead to synergistic interactions (Wennier et al., 2011). Oncolytic viruses as a standalone therapeutic intervention have rarely been shown to induce complete, long-term regression of established tumors in vivo (Vaha-Koskela et al., 2007). The use of recombinant OVs as clinical biotherapies, it is important to determine whether viremia could be induced that could result in shedding of the OV. The use of Ad 5 - prime/MG1-booster vaccination as a promising, novel therapy for testing in the context of veterinary clinical trials (Doronin et al., 2009; Thorne et al., 2007).

The efficiency of OV replication in tumor bearing immunocompetent dogs may be enhanced by various means such as combination of viro- with chemo-(MacTavish et al., 2010) or radiation therapy (Advani et al., 2011) or the conjunctive use of different oncolytic viruses (Le Boeuf et al., 2010). Recombinant vaccinia vectors encoding tumor associated antigens have demonstrated antitumor activity in murine tumor models (Kirn and Thorne, 2009; Thorne et al., 2005). A new generation of oncolytic vaccinia viruses co-expressing tumor antigens and a variety of proinflam matory cytokines has shown improved therapeutic responses and induction of tumor specific immunity in animal models and early-phase clinical studies (Liu et al., 2008; Park et al., 2008).

Induction of antitumor immunity is likely aided by oncolytic-mediated cell death and release of tumor antigens and danger signals, such as ATP and high mobility group box-1, into the extracellular microenvironment (Guo et al., 2005). Viral-mediated oncolysis that induces release of these and other immunogenic signature mole 
cules (example, calreticulin) during cell death can promote an antitumor immune response and be further enhanced by viral expression of immunomodulatory transgenes (eg, GM-CSF). The potential benefit of this approach was initially reported for a recombinant vaccinia virus encoding GM-CSF that abrogated formation of B16 melanoma tumors in mouse models (Thorne et al., 2007). A number of clinical trials have combined oncolytic viruses with a second form of therapy. These trials include widely used chemotherapeutics, such as cisplatin or radiation, and these trials have shown a high frequency of clinical responses (Russell et al, 2012).

The effect of the combination of an oncolytic measle virus with the novel oral HDACi resminostat (Res) was checked in HCC cell panels. The combination effect showed a boosted cytotoxic effect as an enhanced induction of apoptosis with improved rate of primary infections (Ruf et al., 2015). The generation of an antitumor immune response is an indirect mechanism of malignant cell death for both OV infected and non-infected cells vasicular stomatitis virus (Pecora et al., 2002). Cyclophosphamide has been shown in preclinical animal models to improve reovirus access to the tumor and preserve neutralizing antibody levels sufficient for prevention of severe toxicity (Qiano et al., 2008). But, they did not appear to affect antibody levels and duration of viremia (Kolb et al., 2015).

Gemcitabine appears to negatively impact late phases of reovirus replication; however, the net effect is synergistic as it accelerates antitumor immunity generation most likely by decreasing immune suppressive cells within the tumor microenvironment (Gujar et al., 2014). Antibody response to Reolysin also appears to be attenuated with this combination strategy (Lolkema et al., 2011). Activation of the programmed death1/programmed death-ligand 1 (PD-1/PD-L1) axis in tumor cells can be induced by oncolytic virotherapy (Mahalingam et al., 2015; Ranki et al., 2016), a finding likely related to natural stimulation of checkpoint molecules in the setting of chronic viral infections in order to minimize tissue damage (Keir et al., 2008).

There are preclinical data for synergy between OVs and immune checkpoint inhibition. In melanoma xenografts, the combination of Reolysin and anti-PD1 antibody significantly prolonged mice survival compared to either agent alone (Rajani et al., 2016). There was evidence of enhanced antitumor cytotoxic $\mathrm{T}$ cell and natural killer (NK) cell activity with the combination therapy. Suppression of antitumor immunity by regulatory $\mathrm{T}$ cells (Treg) in Reolysin alone treated mice was ameliorated by anti-PD1 therapy. In an immunotherapy resistant lung adenocarcinoma animal model, treatment with oncolytic adenovirus plus anti-PD-1 antibody significantly increased antitumor immune responses to multiple neoantigens and decreased tumor growth, suggesting reversal of anti-PD-1 resistance with oncolytic virotherapy (Woller et al., 2015).

NDV combined with immune checkpoint inhibition in immunogenic and non-immunogenic tumor animal models led to increased antitumor immunity and efficacy compared to either agent alone (Zamarin et al., 2014). Synergy of oncolytic VSV with anti-PD1 antibody therapy has been also demonstrated in glioma models (Cockle et al., 2016). Synergy of ITu vaccinia virus with ITu immune checkpoint blockade and radiation had been established in a lymphoma xenograft model, with tumor shrinkage in both treated and untreated tumors (Minev et al., 2014). The results of oncolytic virotherapy and immune checkpoint inhibition in a Phase I clinical trial are promising (Puzanov et al., 2015).

\subsubsection{Biosafety of Treatment}

The tumor normal immune viral dynamics 1-4 days in the presence of immune response triggered by the escalated viral infection of normal cells. This is very important because the induction of activated $\mathrm{CD} 8^{+} \mathrm{T}$ cells into the tumor site may limit subsequent oncolytic virus spread and intratumoral infection. It is important to note that the innate immune response against the virally infected cells is often active in about 2-7 days post-infection (Carolan et al., 2016).

Non-replicating or replicating viruses can be used as a gene transfer vector to introduce for example a therapeutic gene, co-stimulatory molecule or cytokine into cancer cells or to prime lymphocytes with tumor antigens in cancer vaccine approaches (Roberts et al., 2006). There are two important aspects to oncolytic virotherapy; there is a direct treatment of tumors with replica ting oncolytic viral vectors alone or in combination with therapeutic transgene delivery, chemo therapy, or radiation therapy. On the other hand, there is indirect increase of antitumor immunity through a modulation of the immune response, as with viral oncolysate vaccine, and tumor protective monoclonal antibodies (Mathias et al., 1994).

Treatment with JX-594 induced antitumor immunity, as evidenced by regression of distant uninjected lesions, and appearance of tumor infiltrating eosinophils, T cells, B cells, and macrophages in injected lesions. Further studies have suggested that the oncolytic activity and transgene expression of JX-594 are highly selective and mediated via several mechanisms, including activation of replication by epidermal growth factor receptor and Ras signaling, cellular thymidine kinase levels, and an abnormal interferon response in tumor cells (Parato et al., 2012).

\subsection{Limitations and Prospects of Cancer Gene Therapy}

The induction of activated $\mathrm{CD}^{+} \mathrm{T}$ cells into the tumor site may limit subsequent oncolytic virus spread and intratumoral infection. Even though they do not model the innate immune responses, it is important to note that the innate immune response against the virally infected cells is often active in about 2-7 days post-infection (Carolan et al., 2016). The role of GM-CSF in promoting proliferation of monocyte-derived suppressor cells 
suggests that caution may be needed when using GM-CSF to enhance the immunostimulatory properties of vaccinia and other viruses (Filipazzi et al., 2007). Tumors can develop multiple barriers to various anticancer therapies, including oncolytic virotherapy. Several mechanisms that may hinder the therapeutic efficacy of OVs and the challenges they pose to the development of improved cancer virotherapies.

\subsubsection{Immunological barriers}

Immune responses against viruses presumably limit ongoing viral replication in immuno competent dogs. In this context, a high level of pre-existing immunity to parental viruses in canine populations might limit the use of oncolytic viruses for cancer therapy. The role of virus neutralizing antibodies following intravenous administration remains to be determined. Use of unrelated viruses from different hosts, such as vaccinia for dog cancers, may solve the problem of pre-existing immunity. However, carrier cell based therapy also provided promising results to escape pre-existing immunity (Fujiwara et al., 2011).

Specific delivery to tumors and escape of the pre-existing antiviral immunity increased the effective local viral dose in the tumor tissue and thus enhanced the oncolytic effects (Hamada et al., 2007; Iankov et al., 2007). In order for an OV to establish a niche within the tumor after systemic administration, the OV has to by pass the liver that may actively sequester a percentage of the administered dose (Alemany et al., 2000). Administering the virus directly within the tumor overcomes this limitation, mainly in the minority of tumors with easily accessible skin and subcutaneous lesions such as melanoma, with an abscopal effect and dissemination in distant sites (Andtbacka et al., 2015; Senzer et al., 2009 and Zamarin et al., 2014).

The adaptive immune system may be a double edge sword, playing a role in both tumor killing and early elimination of viral infection through humoral (example, antibody and complement binding) and cellular mechanisms (Wakimoto et al., 2003). Exogenous factors include cellular stress resulting from chemo- and/or radiotherapy and reovirus modulation of interferon signaling (Prestwich et al., 2008). The presence of "infected" tumor cells and the release of viral- and tumor associated antigens after tumor cell lysis, induce robust innate and adaptive antitumor immune responses (Adair et al., 2013; Gujar and Lee, 2014; Hall et al., 2012).

Combination therapy can overcome pre-existing immunity to reovirus without affecting metastatic tumor regression. Reovirus has been shown to preferentially infect, induce ER stress and kill Ras-activated pancreatic cancer cells (Carew et al., 2013). Furthermore, IP admin istration of RV inhibits the peritoneal dissemination of pancreatic cancer cells in a syngeneic immunocompetent animal model (Hirano et al., 2009). Intraportal administration of reovirus has decreased the number and size of treated tumors in the same model (Himeno et al., 2005).

This therapeutic approach faces a major challenge consisting of the immune system's response to the virus, which hinders oncolytic virotherapy. To date, complex dynamics of oncolytic viral tumor infection and the consequences of OV-induced immune response are poorly understood (Workenhe et al., 2015; Woller et al., 2014 and Alvarez-Breckenridge et al., 2015). Denderitic cells and NK cells produce a range of cytokines that promotes $\mathrm{T}$ helper 1 cell activity and potent cytotoxic $\mathrm{T}$ lymphocyte responses that are necessary for clearing virus-infected cells (Romagn ani et al., 2005).

Additionally, humoral immune responses, namely the production of neutralizing antibodies by B cells and plasma cells, provide several lines of antiviral defense (Dorner and Radbruch, 2007). Plasma cells derived from $\mathrm{B} 1$ cells imparts early defense against viral infection by producing polyspecific antibodies. $\mathrm{CD}^{+} \mathrm{T}$ helper cells then stimulate naive B cells at later stages, in order to generate memory B cells and long-lived plasma cells that produce high amounts of specific neutralizing IgG antibodies. Finally, the complement system, composed of soluble factors and cell surface receptors, blocks viral infection by acting on both the innate and adaptive immune responses. These mechanisms include, enhancing humoral immunity, regulating antibody effector mechanisms, and modulating T cell function (Stoermer and Morrison, 2010).

The infectious potential of recognized OVs (example, Ad, HSV) becomes limited by high levels of neutralizing antibodies (Massari et al., 2002). These circulating antibodies can limit viruses from ever reaching the tumor site, especially since some viral particles, including HSV-1- and murine leukemia virus-derived viruses, are particularly prone to inactive action by the comple ment system (Ikeda et al., 2000). Poxviruses elicit a strong cell mediated immune response and are ultimately cleared from the body by the humoral immune system, preventing poxviruses from causing latent or recurrent infection (Chaudhri et al., 2004).

\subsubsection{Tumor environment}

The immune system has often being perceived as a major impediment to successful oncolytic virus therapy by facilitating viral clearance (Prestwich et al., 2009 and Bridle et al., 2010). Even though intratumoral viral injections offer direct tumor infection, they are of limited use in regions (such as the brain) where the tumor cannot be reached directly (Crittenden et al., 2005). Intrinsic barriers within the tumor microenvironment, such as dense intratumoral connective tissue and induction of antiviral immunity, can impair these processes. Alteration of the microenvironment by administering exogenous enzymes directly to the tumor or by equipping viruses to encode recombinant enzymes can facilitate viral spread (Guedan et al., 2010).

Tumor-infiltrating leukocytes can negatively regulate immune responses within the tumor, which include 
regulatory T cells (Tregs), myeloid derived suppressor cells, and type 2 macrophages. Their immunosuppressive functions can be exerted by secretion of cytokines (e.g., IL-10 and TGF- $\beta$ ), through inhibitory receptors (e.g. CTLA-4 and PD-L1) via cell contact, and secretion of amino-acid depleting enzymes (arginase and IDO) in the tumor microenvironment. Tumor cells themselves also have mechanisms to suppress antitumor immunity, such as the shedding of NKG2D ligands, MICA/B that blocks NK cell and T cell function (Groh et al., 2002) and facilitates the expansion of immunosuppressive $\mathrm{CD}^{+} \mathrm{T}$ cells (Groh et al., 2006).

Oncolytic virotherapy has the potential benefit of altering the tumor microenvironment enough to break existing tumor immunotolerance. Failure of the immune system to recognize tumor cells may be due to a paucity of stimulated immune cells infiltrating the tumor and/or masking of tumor or antigens. Aberrant cytokine patterns in the tumor microenvironment may severely limit an antitumor immune response (Zou, 2005).

\subsubsection{Challenges of combination theraphy}

Although seropositivity for herpes simplex virus is common and could prevent booster inject- ions, preclinical and clinical data suggest that pre-existing antiherpes antibody titers do not appreciably impact therapeutic responses, which may relate to the intratumoral route of admin isteration. Because local antiviral immunity may limit therapeutic efficacy, strategies to limit local immune response have been used to enhance the oncolytic activity of herpes simplex virus vectors. For example, cyclophosphamide has been used to block bone marrow-derived generation of inflammatory cells prior to administration of herpes simplex virus (Currier et al., 2008; Fulci et al., 2006).

Another approach is the use of agents either exogenously administered (eg. cilengitide, bevacizumab) or re engineered into the virus (eg. vasculostatin) to inhibit vascular permeability or formation of neovasculature in the tumor to limit the extravasation of inflammatory cells into the tumor, and permit enhanced virus production in tumor cells (Kaur et al., 2005; Kurozumi et al., 2008). Introducing genes that are make cancer cells more sensitive to standard chemotherapy or for radiation treatments. Drug convertases ("suicide genes") which can turn an inactive prodrug into an active drug which can be introduced to tumor cells to cause cell-specific toxicity. For example, the herpesvirus thymidine kinase can phosphorylate and convert nontoxic drug ganciclovir into toxic metabolites (Mullen and Tanabe, 2003).

Serum from individuals who were sero-positive for CVA21 failed to show cross-neutralization to other group A coxsackie viruses, that is, A13, A15, or A18. Thus, prime boost strategies utilizing alternate strains of coxsackie A virus might be one approach to increase antitumor immunity and therapeutic responses with oncolytic coxsackie viruses (Au et al., 2011). However, as far as veterinary medicine is concerned, development of oncolytic virotherapy for cancer to heal canine patients is of prime importance. Many of the treatment options used in veterinary medicine rese- mble protocols used to treat human cancer patients. In addition, public release of nearly $99 \%$ canine genome sequences provided a window of opportunity to expand the scope of comparative oncology (MacTavish et al., 2010).

The most common immunosuppressant drug used in the context of oncolytic virotherapy is cyclophosphamide; a chemotherapeutic alkylating agent that also induces apoptotic cell death. CPA has complex immune-modulating effects, affecting humoral and cellular mediators of both the innate and acquired immune responses. These immunosuppressive functions have been shown to enhance viral oncolysis and improve antitumor efficacy of HSV (Ikeda et al., 2003; Kambara et al., 2005). Some OVs can actually stimulate angiogenesis to increase vascular perm eability in tumors (Aghi et al., 2007).

Thus, anti-angiogenic therapy may thus adversely affect the localization of OVs to the tumor microenvironment. Finally, modulation of the host immune response through chemotherapy may conflict with the therapeutic function of the oncolytic virus. For instance, low dose CPA may remove immunosuppressive cells such as Tregs to improve vaccine induced adaptive antitumor immune responses; however, it also promotes the antiviral immune response, leading to early viral clearance (Bartlett et al., 2013). Conversely, high dose CPA may enhance viral oncolysis through wide spread immunosuppression of the innate and adaptive antiviral immune response, but also completely abrogate the antitumor immune response (Prestwich et al., 2008).

\section{CONCLUSION}

Oncolytic virotherapy constitutes an alternative treatment option for a broad spectrum of cancer entities and quickly moving toward the forefront of modern medicines. By direct and indirect mechanisms of tumor killing, virotherapy provide rationale for investigation of clinical trials using engineered OVs in support of conventionl cancer therapy as well as in combination with immune checkpoint inhibitors. In general the tumor selective property of oncolytic viruses method is based on the capability of OVs to preferentially infect and lyses cancer cells and to initiate specific antitumor immune response. After genetic engineering, The other advantage of oncolytic virotherapy is that, OVs selectively replicate in cancer cells leads to tumor cell destruction and oncolysis. On top of this, a better understanding of the functional roles of various viral genes has aided the modification of oncolytic viruses to alter tumor selectivity, pathogenicity, and immunogenicity, and to optimize the clinical potential of these vectors. Concomint to the current encouragement of more study on oncolytic virus enter human 
clinical trials, more oncolytic therapeutics may become available for use in companion animals in near future. Hence, further investigation is needed to give attention on type of cancers and stages of disease, viral dose and mode of immune cells enforced. Further research on the optimization of the OV-drug combination strategies for both the oncolytic and antitumor immune effects of OVs is requires. On top of this, the clinical impact of oncolytic viruses and the potential promise of this approach for the treatment of animal cancers need to be investigated.

\section{Competing Interests}

The authors declare that they have no competing interests.

\section{Acknowledgments}

The authors are thankful to library and ICT office of Hawassa University for providing the facilities to prepare this review paper.

\section{REFERENCES}

Adair, R.A., Scott, K.J., Fraser, S., Errington-Mais, F., Pandha, H., Coffey, M., Selby, P., Cook, G.P., Vile, R., Harrington, K.J., Toogood, G., Melcher, A.A. (2013): Cytotoxic and immune-mediated killing of human colorectal cancer by reovirus-loaded blood and liver mononuclear cells. Int. J. Cancer., 132: 2327-38.

Adelfinger, M., Gentschev, I., Grimm de Guibert, J., Weibel, S., Härtl, B., (2014): Evaluation of a new recombinant oncolytic vaccinia virus strain GLV-5b451 for feline mammary carcinoma therapy.

Advani, S.J., Markert, J.M., Sood, R.F., Samuel, S., Gillespie, G.Y., Shao, M.Y., Roizman, B., Weichselbaum, R.R. (2011): Increased oncolytic efficacy for high-grade gliomas by opti mal integration of ionizing radiation into the replicative cycle of HSV-1. Gene Therapy. Volume and page?

Aghi, M., Rabkin, S.D., Martuza, R.L. (2007): Angiogenic response caused by oncolytic herpes simplex virusinduced reduced thrombospondin expression can be prevented by specific viral mutations or by administering a thrombospondin-derived peptide. Cancer Res., 67(2): 410-440.

Alain, T., Kim, M., Johnston, R.N., Urbanski, S., Kossakowska, A.E., Forsyth, P.A. (2006): The oncolytic effect in vivo of reovirus on tumour cells that have survived reovirus cell killing in vitro. Br. J. Cancer., 95(8): 710 1020.

Alcayaga-Miranda, F., Cascallo, M., Rojas, J.J., Pastor, J., Alemany, R. (2010): Osteosarcoma cells as carriers to allow antitumor activity of canine oncolytic adenovirus in the presence of neutralizing antibodies. Cancer Gene Ther., 17: 792-802.

Al-Dissi, A.N., Haines, D.M., Singh, B. (2010): Kidney BA.Immunohistochemical expression of vascular endothelial growth factor and vascular endothelial growth factor receptor-2 in canine simple mammary gland adenocarcinomas. Can. Vet. J., 51: 1109-1114.

Alemany, R. (2013): "Viruses in cancer treatment".Clinical and Translational Oncol., 15 (3): 182-8.

Alemany, R., Suzuki, K., Curiel, D.T. (2000): Blood clearance rates of adenovirus type 5 in mice. J. Gen. Virol., 81: 2605-09.

Allen, C., Opyrchal, M., Aderca, I., (2013): Oncolytic measles virus strains have significant antitumor activity against glioma stem cells. Gene Ther., 20(4): 444-449.

Alvarez-Breckenridge, C.A., Choi, B.D., Suryadevara, C.M., Chiocca, E.A. (2015): Potentiating oncolytic viral therapy through an understanding of the initial immune responses to oncolytic viral infection. Current opinion in virol., 25: 25-32.

Amorim, R.L., Pinczowski, P., Neto, R.T., Rahal, S.C. (2010): Immunohistochemical evaluation of prostaglandin E2 and vascular endothelial growth factor in canine cutaneous mast cell tumours. Vet. Comp. Oncol., 8: 2327.

An, Y., Liu, T., He, J., Wu, H., Chen, R., Liu,Y. (2016): Recombinant Newcastle disease virus expressing P53 demonstrates promising antitumor efficiency in hepatoma model. J. Biomed. Sci. Jul, 28., 23(1): 55.

Anderson, B.D., Nakamura, T., Russell, S.J., Peng, K.W. (2004): High CD46 receptor density determines preferential killing of tumor cells by oncolytic measles virus. Cancer Res., 64: 4919-26.

Andtbacka, R.H., Kaufman, H.L., Collichio, F., Amatruda,T., Senzer, N., Chesney, J., Delman, K.A., Spitler, L.E., Puzanov, I., Agarwala, S.S., Milhem, M., Cranmer, L., Curti, B. (2015): Talimogene Laherparepvec Improves Durable Response Rate in Patients With Advanced Melanoma. J. Clin. Oncol., 33: 2780-88..

Atherton, M. and Lichty, B.D. (2013): Evolution of oncolytic viruses: Novel strategies for cancer treatment. Immunotherapy, 5: 1191-1206.

Au, G.G., Beagley, L.G., Haley, E.S, Barry, R.D., Shafren, D.R.(2011): Oncolysis of malignant human melanoma tumors by Coxsackieviruses A13, A15 and A18. Virol. J., 8: 22.

Bai. F.L., Yu, Y.H., Tian, H., Ren, G.P., Wang, H., Zhou, B. (2014): Genetically engineered Newcastle disease virus expressing interleukin-2 and TNF-related apoptosis-inducing ligand for cancer therapy. Cancer Biol. Ther., 15(9): 1226-1238.

Bartlett, D.L., Liu, Z., Sathaiah, M., Ravindranathan, R., Guo, Z., He, Y. (2013): Oncolytic viruses as therapeutic 
cancer vaccines. Mol. Cancer, 12(1): 103.

Benencia, F., Courreges, M.C., Conejo-García, J.R., Buckanovich, R.J., Zhang, L., Carroll, R.H., Morgan, M.A., Coukos, G. (2005): Oncolytic HSV exerts direct antiangiogenic activity in ovarian carcinoma. Human Gene Ther., 16: 765-78.

Bian, H., Wilden, H., Fournier, P., Peeters, B., Schirrmacher, V. (2006): In vivo efficacy of systemic tumor targeting of a viral RNA vector with oncolytic properties using a bispecific adapter protein. Int. J. Oncol., 29(6): 1359-1369.

Bischoff, J.R., Kirn, D.H., Williams, A., Heise, C., Horn, S., Muna, M., Ng, L., Nye, J.A., Sampson-Johannes, A., Fattaey, A., McCormick, F. (1996): An adenovirus mutant that replicates selectively in p53-deficient human tumor cells. Scien., 274: 373-376.

Blechacz, B., Splinter, P.L., Greiner, S., Myers, R., Peng, K.W., Federspiel, M.J., Russell, S.J., LaRusso, N.F.(2006): Engineered measles virus as a novel oncolytic viral therapy system for hepato cellularcarcinoma.Hepatology., 44: 1465-77.

Breitbach, C.J., Arulanandam, R., De Silva, N., Thorne, S.H, Patt, R., Daneshmand, M., Moon, A., Ilkow, C., Burke, J., Hwang, T.H., Heo. J., Cho, M., Chen, H. (2013): Oncolytic vaccinia virus disrupts tumor-associated vasculature in humans. Cancer Res., 73: 1265-75.

Breitbach, C.J., De Silva, N.S., Falls, T.J., Aladl, U., Evgin, L., Paterson, J., Sun, Y.Y., Roy., D.G., RintoulJL, Daneshmand, M., Parato, K., Stanford, M.M., Lichty, B.D. (2011): Targeting tumor vasculature with an oncolytic virus. Mol Ther., 19: 886-94.

Breitbach, C.J., Lichty, B.D., Bell, J.C. (2016): Oncolytic Viruses: therapeutics with an identity crisis. Ebio Medicine., 9: 31-36.

Breitbach, C.J, Paterson, J.M., Lemay, C.G., Falls, T.J., McGuire, A. (2007): Targeted inflammation during oncolytic virus therapy severely compromises tumor blood flow. Mol. Ther., 15: 1686-1693.

Buonaguro, F.M., Tornesello, M.L., Izzo, F., Buonaguro, L. (2012): Oncolytic virus therapies. Pharm. Pat. Anal., 1(5): $621-710$.

Carew, J.S., Espitia, C.M., Zhao, W., Kelly, K.R., Coffey, M., Freeman, J.W., Nawrocki, S.T. (2013): Reolysin is a novel reovirus-based agent that induces endoplasmic reticular stress-mediated apoptosis inpancreaticcancer. Cell Death Dis., 4: 728.

Carolan, L.A., Rockman, S., Borg, K., Guarnaccia, T., Reading, P., Mosse, J. (2016): Charact erization of the Localized Immune Response in the Respiratory Tract of Ferrets following Infection with Influenza A and B Viruses. J. of virol., 90(6): 2838-2848.

Carter, G.C., Law, M., Hollinshead, M., Smith, G.L. (2005): Entry of the vaccinia virus intracellular mature virion and its interactions with glycosaminoglycans. J, Gen. Virol.,86: 1279-1290

Casjens, S. (2010): "Oncolytic virus".In Mahy BW, Van Regenmortel MH.Desk Encyclopedia of General Virology. Boston: Academic Press. 167.

Chaudhri, G., Panchanathan, V., Buller, R.M., (2004): Polarized type 1 cytokine response and cell-mediated immunity determine genetic resistance to mousepox. Proc Natl Acad Sci U S A., 101(24): 9057-9062.

Chen, N.G. and Szalay, A.A. (2011): Cancer Management in Man: Chemotherapy, Biological Therapy, Springer; New York, NY, USA: Hyperthermia and Supporting Measures. Oncolytic Virotherapy of Cancer., 13295 316.

Chen, Y., Williams, V., Filippova, M., Filippov, V., Duerksen-Hughes, P. (2014): Viral carcinogenesis: factors inducing DNA damage and virus integration. Cancers.,6: 2155-86.

Chu, R.L., Post, D.E., Khuri, F.R., Van Meir, E.G. (2004): Use of replicating oncolytic adenoviruses in combination therapy for cancer. Clin Cancer Res., 10(16): 5299-312.

Clarke, P. and Tyler, K.L. (2007): Down-regulation of cFLIP following reovirus infection sensitizes human ovarian cancer cells to TRAIL-induced apoptosis. Apoptosis., 12(1): 211-223.

Cockle, J.V., Rajani, K., Zaidi, S., Kottke, T., Thompson, J., Diaz, R.M., Shim, K., Peterson, T., Parney. I.F., Short, S., Selby, P., Ilett, E., Melcher, A., Vile, R. (2016): Combination viroimmunotherapy with checkpoint inhibition to treat glioma, based on location-specific tumor profiling. Neuro-oncol., 18: 518-27.

Connolly, J.L., Rodgers, S.E., Clarke, P. (2000): Reovirus-induced apoptosis requires activation of transcription factor NF-kappaB. J, Virol., 74: 2981-2989.

Correa, R.J., Komar, M., Tong, J.G. (2012): Myxoma virus-mediated oncolysis of ascites-derived human ovarian cancer cells and spheroids is impacted by differential Akt activity. Gynecol Oncol., 125(2): 441-450.

Crittenden, M.R., Thanarajasingam, U., Vile, R.G., Gough, M.J. (2005): Intratumoral immunotherapy: using the tumour against itself. Immunology., 114(1): 11-22.

Csatary, L.K., Gosztonyi, G., Szeberenyi, J. (2004): MTH-68/H oncolytic viral treatment in human high-grade gliomas. J, Neurooncol., 67(1-2): 83-93.

Currier, M.A., Gillespie, R.A., Sawtell, N.M., et al. (2008): Efficacy and safety of the oncolytic herpes simplex virus rRp450 alone and combined with cyclophosphamide. Mol. Ther., 16(5): 879-885. 
De Queiroz, G.F., Dagli, M.L., Fukumasu, H., Zavala, A.A., Matera, J.M.(2010): Vascular endothelial growth factor expression and microvascular density in soft tissue sarcomas in dogs. J, Vet. Diagn Invest., 22: 105108.

Diaconu, I., Cerullo, V., Hirvinen, M.L., Escutenaire, S., Ugolini, M., Pesonen, S.K., Bramante, S., Parviainen, S., Kanerva, A., Loskog, A.S., Eliopoulos,G., Pesonen. S., Hemminki, A. (2012): Immune response is an important aspect of the antitumor effect produced by a CD40L-encoding oncolytic adenovirus. Cancer Res.,72: 2327-38.

Donnelly, O.G., Errington-Mais, F., Steele, L., Hadac, E., Jennings, V., Scott, K., Peach, H., Phillips, R.M., Bond, J., Pandha, H., Harrington, K., Vile, R., Russell, S. (2013): Meas les virus causes immunogenic cell death in human melanoma. Gene Ther., 20: 7-15.

Dorner, T., and Radbruch, A. (2007):Antibodies and B cell memory in viral immunity. Immunity., 27(3): 384-92.

Doronin, K., Shashkova, E.V., May, S.M., Hofherr, S.E., Barry, M.A. (2009): Chemical modification with high molecular weight polyethylene glycol reduces transduction of hepatocytes and increases efficacy of intravenously delivered oncolytic adenovirus. Hum Gene Ther., 20(9): 975-988.

Dunn, G.P., Koebel, C.M., Schreiber, R.D. (2006): Interferons, immunity and cancer immuno editing. Nat. Rev. Immunol., 6: 836-848.

Elankumaran, S., Rockemann, D., Samal, S.K. (2006): Newcastle disease virus exerts oncolysis by both intrinsic and extrinsic caspase-dependent pathways of cell death. J. Virol., 80(15): 7522-7534.

Elankumaran, S., Chavan, V., Qiao, D., Shobana, R., Moorkanat, G., Biswas, M. (2010): Type I interferonsensitive recombinant newcastle disease virus for oncolytic virotherapy. J. Virol., 84(8): 3835-3844.

Engeland, C.E., Grossardt, C., Veinalde, R., Bossow, S., Lutz, D., Kaufmann, J.K., Shevchenko, I., Umansky, V., Nettelbeck, D.M., Weichert, W., Jäger, D., von Kalle, C., Ungerechts, G.(2014): CTLA-4 and PD-L1 checkpoint blockade enhances oncolytic measles virus therapy. Mol Ther., 22: 1949-59.

Ferguson, M.S., Lemoine, N.R., Wang, Y. (2012):"Systemic delivery of oncolytic viruses: hopes and hurdles". Advances in Virol., 8: 1-14.

Ferrara, N., Gerber, H.P., LeCouter, J. (2003): The biology of VEGF and its receptors. Nat. Med., 9: 669-676.

Filipazzi, P., Valenti, R., Huber, V. (2007): Identification of a new subset of myeloid suppressor cells in peripheral blood of melanoma patients with modulation by a granulocyte-macrophage colony- stimulation factor-based antitumor vaccine. J. Clin. Oncol., 25(18): 2546-2553.

Fishelson, Z., Donin, N., Zell, S., Schultz, S., Kirschfink, M. (2003): Obstacles to cancer immunotherapy: expression of membrane complement regulatory proteins (mCRPs) in tumors. Mol Immunol., 40: 109-23.

Fournier, P., Bian, H., Szeberényi, J., Schirrmacher, V. (2012): Analysis of three properties of Newcastle disease virus for fighting cancer: tumor-selective replication, antitumor cytotoxicity, and immunostimulation. Methods Mol. Biol., 797: 177-204.

Fridlender, Z.G., Sun, J., Kim, S., Kapoor, V., Cheng, G. (2009): Polarization of tumor-associated neutrophil phenotype by TGF-beta: "N1" versus "N2" TAN. Cancer Cell., 16: 183-194.

Fujiwara, S., Nawa, A., Luo, C., Kamakura, M., Goshima, F., Kondo, C., Kiyono, T., Kikkawa, F., Nishiyama, Y. (2011): Carrier cell-based delivery of replication-competent HSV-1 mutants enhances antitumor effect for ovarian cancer. Cancer Gene Ther., 18: 77-86.

Fulci, G., Breymann, L., Gianni, D., (2006): Cyclophosphamide enhances glioma virotherapy by inhibiting innate immune responses. Proc Natl Acad Sci U S A., 103(34): 12873-12878.

Gaggar, A., Shayakhmetov, D.M., Liszewski, M.K., Atkinson, J.P., Lieber, A. (2005): Loca lization of regions in CD46 that interact with adenovirus. J, Virol., 79(12): 7503-7513.

Geletneky, K., Hartkopf, A.D., Krempien, R., Rommelaere, J., Schlehofer, J.R. (2010): Improved killing of human high-grade glioma cells by combining ionizing radiation with oncolytic parvovirus $\mathrm{H}-1$ infection. J, Biomed Biotechnol., 2010: 350748. 10.1155/2010/350748. Volume and page?

Geletneky, K., Kiprianova, I., Ayache, A., Koch, R., Herrero, Y., Calle, M. (2010): Regression of advanced rat and human gliomas by local or systemic treatment with oncolytic parvovirus H-1 in rat models. Neuro Oncol., 12: 04-14.

Gentry, G.A. (1992): "Viral thymidine kinases and their relatives". Pharmacology and Therap eutics., 54 (3): 19 55.

Gentschev, I., Patil, S.S., Adelfinger, M., Weibel, S., Geissinger, U. (2013): Characterization and evaluation of a new oncolytic vaccinia virus strain LIVP6.1.1 for canine cancer therapy. Bio. engineered., 4: 84-89.

Gentschev, I., Adelfinger, M., Josupeit, R., Rudolph, S., Ehrig, K., Donat, U., Weibel, S., Chen, N.G., Yu, Y.A., Zhang, Q. (2012): Preclinical evaluation of oncolytic vaccinia virus for therapy of canine soft tissue sarcoma. PLoS One., 7: 37-39.

Gentschev, I., Ehrig, K., Donat, U., Hess, M., Rudolph, S., Chen, N., Yu, Y.A., Zhang, Q., Bullerdiek, J., Nolte, I. (2010): Significant Growth Inhibition of Canine Mammary Carcinoma Xenografts following Treatment with Oncolytic Vaccinia Virus GLV-1h68. J. Oncol. 736907:1-736907:10. Volume and page? 
Gentschev, I., Stritzker, J., Hofmann, E., Weibel, S., Yu, Y.A., Chen, N., Zhang, Q., Bullerdiek, J., Nolte, I., Szalay, A.A. (2009): Use of an oncolytic vaccinia virus for the treatment of canine breast cancer in nude mice: Preclinical development of a therapeutic agent. Cancer Gene Ther., 16: 320-328.

Ginsberg, H.S. (2013): The Adenoviruses, Springer, US, 2013.

Gobar, G.M., Case, J.T., Kass, P.H. (1998): Program for surveillance of causes of death of dogs, using the Internet to survey small animal veterinarians. J, Am Vet Med Assoc., 213: 251-256.

Groh, V., Smythe, K., Dai, Z., Spies, T. (2006): Fas-ligand-mediated paracrine T cell regulation by the receptor NKG2D in tumor immunity. Nat Immunol., 7(7): 755-62.

Groh, V., Wu, J., Yee, C., Spies, T. (2002): Tumour-derived soluble MIC ligands impair expression of NKG2D and T-cell activation. Nature., 419(6908): 734-810.

Guedan, S., Rojas, J.J., Gros, A., Mercade, E., Cascallo, M., Alemany, R. (2010): Hyaluronidase expression by an oncolytic adenovirus enhances its intratumoral spread and suppresses tumor growth. Mol Ther., 18(7): 12751283.

Gujar, S.A., Clements, D, Dielschneider, R., Helson, E., Marcato, P., Lee, P.W. (2014): Gemcitabine enhances the efficacy of reovirus-based oncotherapy through anti-tumour immunological mechanisms. Br. J. Cancer., 110: $83-93$.

Gujar, S. A., Lee, P.W. (2014): Oncolytic virus-mediated reversal of impaired tumor antigen presentation. Front. Oncol., 4: 77.

Guo, Z.S., Naik, A., O’Malley, M.E., et al. (2005): The enhanced tumor selectivity of an oncolytic vaccinia lacking the host range and antiapoptosis genes SPI-1 and SPI-2. Cancer Res., 65(21): 9991-9998.

Guo, Z.S., Thorne, S.H., Bartlett, D.L. (2008): Oncolytic virotherapy: molecular targets in tumor-selective replication and carrier cell-mediated delivery of oncolytic viruses. Biochimica et Biophysica Acta (BBA)Reviews on Cancer., 1785(2): 217-231.

Gupta, V., Wang, W., Sosnowski, B.A., Hofman, F.M., Chen, T.C. (2006): Fibroblast growth factor-2-retargeted adenoviral vector for selective transduction of primary glioblastoma multiforme endothelial cells. Neurosurg Focus., 20(4): 26.

Hall, K., Scott, K,J., Rose, A., Desborough, M., Harrington, K., Pandha, H., Parrish, C., Vile, R., Coffey, M., Bowen, D., Errington-Mais, F., Melcher, A.A.(2012): Reovirus-mediated cytotoxicity and enhancement of innate immune responses against acute myeloid leukemia.Biores Open Access., 1: 3-15.

Hamada, K., Desaki, J., Nakagawa, K., Zhang, T., Shirakawa, T., Gotoh, A., Tagawa, M. (2007): Carrier cellmediated delivery of a replication-competent adenovirus for cancer gene therapy. Mol. Ther., 15: 1121-1128.

Hemminki, A., Kanerva, A., Kremer, E.J., Bauerschmitz, G.J., Smith, B.F., Liu, B., Wang, M., Desmond, R.A., Keriel, A., Barnett, B. (2003): A canine conditionally replicating adenovirus for evaluating oncolytic virotherapy in a syngeneic animal model. Mol. Ther., 7: 163-173.

Hicklin, D.J. and Ellis, L.M. (2003): Role of the vascular endothelial growth factor pathway in tumor growth and angiogenesis.J, Clin Oncol., 23: 1011-1027.

Himeno, Y., Etoh, T., Matsumoto, T., Ohta, M., Nishizono, A., Kitano, S. (2005): Efficacy of oncolytic reovirus against liver metastasis from pancreatic cancer in immunocompetent models. Int. J. Oncol., 27: 901-06.

Hirano, S., Etoh, T., Okunaga, R., Shibata, K., Ohta, M., Nishizono, A., Kitano, S. (2003): Reovirus inhibits the peritoneal dissemination of pancreatic cancer cells in an immunocompetent animal model. Oncol Rep., 21: $1381-84$.

Hlavaty, J., Jandl, G., Liszt, M., Petznek, H., Konig-Schuster, M., Sedlak, J., Egerbacher, M., Weissenberger, J., Salmons, B., Gunzburg, W,H., Renner, M. (2011): Comparative evaluation of preclinical in vivo models for the assessment of replicating retroviral vectors for the treatment of glioblastoma. J, Neurooncol., 102: 59-69.

Hwang, C.C., Umeki, S., Kubo, M., Hayashi,T., Shimoda, H., Mochizuki, M., Maeda, K., Baba, K., Hiraoka, H., Coffey, M. (2013): Oncolytic reovirus in canine mast cell tumor. PLoS One., 8: e73555. Volume and page?

Iankov, I.D., Blechacz, B., Liu, C., Schmeckpeper, J.D., Tarara, J.E., Federspiel, M.J., Caplice, N., Russell, S.J. (2007): Infected cell carriers: a new strategy for systemic delivery of oncolytic measles viruses in cancer virotherapy. Mol Ther., 15: 114-122.

Idema, S., Geldof, A.A., Dirven, C.M. (2007): Evaluation of adenoviral oncolytic effect on glio ma spheroids by 18F-DG positron-emission tomography. Oncol Res., 16(10): 471-477.

Ikeda, K., Wakimoto, H., Ichikawa, T., Jhung, S., Hochberg, F.H., Louis, D.N. (2000): Comple ment depletion facilitates the infection of multiple brain tumors by an intravascular, replication-conditional herpes simplex virus mutant. J. Virol., 74(10): 4765-7510.

Jablonska, J., Leschner, S., Westphal, K., Lienenklaus, S., Weiss. S. (2010): Neutrophils responsive to endogenous IFN-beta regulate tumor angiogenesis and growth in a mouse tumor model. J. Clin. Invest., 120: 1151-1164.

Jin, F., Xie, Z., Kuo, CJ, Chung, L.W., Hsieh, C.L. (2005): Cotargeting tumor and tumor endothelium effectively inhibits the growth of human prostate cancer in adenovirus-mediated antiangiogenesis and oncolysis combination therapy. Cancer Gene Ther., 12(3): 257-267. 
Jourdier, T.M., Moste, C., Bonnet, M.C., Delisle, F., Tafani, J.P. (2003): Local immuno therapy of spontaneous feline fibrosarcomas using recombinant poxviruses expressing interleukin 2 (IL2). Gene Ther., 10: 21262132.

Josupeit, R., Bender, S., Kern, S. (2016): Pediatric and adult high-grade glioma stem cell culture models are permissive to lytic infection with parvovirus H-1. Viruses., 8(5): 138.

Kambara, H., Saeki, Y., Chiocca, E.A. (2005): Cyclophosphamide allows for in vivo dose reduction of a potent oncolytic virus. Cancer Res., 65(24): 11255-810.

Kanaya, N., Yazawa, M., Goto-Koshino, Y., Mochizuki, M., Nishimura, R., Ohno, K., Sasaki, N., Tsujimoto, H. (2011): Anti-tumor effect of adenoviral vector-mediated p53 gene transfer on the growth of canine osteosarcoma xenografts in nude mice. J. Vet. Med. Sci., 73: 877-883..

Kanerva, A., P. Nokisalmi, P., Diaconu, I. (2013): "Antiviral and antitumor T-cell immunity in patients treated with GM-CSF-coding oncolytic adenovirus,".Clinical Cancer Research, vol. 19(10): 2734-2744.

Kaufman, H.S., Kohlhapp, F.J., and Zloza, A. (2015): "Oncolytic viruses: a new class of immunotherapy drugs,".Nature Reviews Drug Discovery, 14(9): 642-662.

Kaur, B., Brat, D.J., Devi, N.S., Van Meir, E.G. (2005): Vasculostatin, a proteolytic fragment of brain angiogenesis inhibitor 1, is an antiangiogenic and antitumorigenic factor. Oncogene., 24(22): 3632-3642.

Keir, M.E., Butte, M.J., Freeman, G.J. (2008): Sharpe AH.PD-1 and its ligands in tolerance and immunity.Annu.Rev Immunol., 26: 677-704.

Kelly, E., Russell, S.J. (2007): History of oncolytic viruses: genesis to genetic engineering. Mol. Ther., 15: 651659.

Kepp, O., Galluzzi, L., Martins, I., Schlemmer, F., Adjemian, S., Michaud, M., Sukkurwala, A.Q .,Menger, L., Zitvogel, L., Kroemer, G. (2011): Molecular determinants of immuno ge nic cell death elicited by anticancer chemotherapy. Cancer Metastasis Rev.,30: 61-69.

Kiprianova, I., Thomas, N., Ayache, A., Fischer, M., Leuchs, B., Klein, M. (2011): Regression of glioma in rat models by intranasal application of parvovirus H-1.Clin. Cancer Res., 17: 5333-42.

Kirn, D.H. and Thorne, S.H. (2009): Targeted and armed oncolytic poxviruses: a novel multi-mechanistic therapeutic class for cancer. Nat. Rev. Cancer., 9(1): 64-71.

Kolb, E.A., Sampson, V., Stabley, D., Walter, A., Sol-Church,K., Cripe, T., Hingorani, P., Ahern, C.H., Weigel, B.J., Zwiebel, J., Blaney, S.M. (2015): A phase I trial and viral clearance study of reovirus (Reolysin) in children with relapsed or refractory extra-cranial solid tumors: a Children's Oncology Group Phase I Consortium report. Pediatr. Blood Cancer., 62: 751-58.

Krishnamurthy, S., Takimoto, T., Scroggs, R.A., Portner, A. (2006): Differentially regulated interferon response determines the outcome of Newcastle disease virus infection in normal and tumor cell lines. J. Virol., 80(11): $5145-55$.

Kruyt, F.A., and Curiel, D.T. (2002): Toward a new generation of conditionally replicating adenoviruses: pairing tumor selectivity with maximal oncolysis. Hum. Gene Ther., 13(4): 485-95.

Lamfers, M. L., Idema, S., Bosscher, L. (2007): Differential effects of combined Ad5-24RGD and radiation therapy in in vitro versus in vivo models of malignant glioma. Clin. Cancer Res., 13(24): 7451-7458.

Lawler, S.E., Speranza, M-C., Cho C-F, Chiocca, E.A. (2016): Oncolytic viruses in cancer treatment: a review. JAMA Oncol., 10: 2016-2064.

Le Boeuf, F., Diallo, J.S., McCart, J.A., Thorne, S., Falls, T., Stanford, M., Kanji, F., Auer, R., Brown, C.W., Lichty, B.D. (2010): Synergistic interaction between oncolytic viruses augments tumor killing. Mol. Ther., 18: 888-895.

Le, L.P., Rivera, A.A., Glasgow, J.N., Ternovoi, V.V., Wu, H., Wang, M., Smith, B.F., Siegal, G.P., Curiel, D.T. (2006): Infectivity enhancement for adenoviral transduction of canine osteosarcoma cells. Gene Ther., 13: 389-399.

Li, P., Chen, C.H., Li,S., Givi, B., Yu, Z., Zamarin, D. (2011): Therapeutic effects of a fusogenic newcastle disease virus in treating head and neck cancer. Head Neck., Oct. 33(10): 1394-1399.

Lichty, B.D., Breitbach, C.J., Stojdl, D.F., Bell, J.C. (2014): "Going viral with cancer immunotherapy". Nature Reviews. Cancer. 14 (8): 559-67.

Liu, B.L., Robinson, M., Han, Z.Q. (2003): ICP34.5 deleted herpes simplex virus with enhanced oncolytic,immune stimulating, and anti-tumour properties. Gene Ther., 10(4): 292-303.

Liu, T.C., Galanis, E., Kirn, D. (2007): Clinical trial results with oncolytic virotherapy: A century of promise, a decade of progress. Nat. Clin. Pract. Oncol., 4: 101-117.

Liu, T.C., Hwang, T, Park, B.H., Bell, J., Kirn, D.H. (2008): The targeted oncolytic poxvirus JX-594 demonstrates antitumoral, antivascular, and anti-HBV activities in patients with hepatocellular carcinoma. Mol Ther., 16(9): 1637-1642.

Liu, T.C., Wang, Y., Hallden, G., Brooks, G., Francis, J., Lemoine, N.R., Kirn, D. (2005): Functional interactions of antiapoptotic proteins and tumor necrosis factor in the context of a replication-competent adenovirus. Gene 
Ther., 12: 1333-1346.

Lolkema, M.P., Arkenau, H.T., Harrington, K., Roxburgh, P., Morrison, R., Roulstone, V., Twigger, K., Coffey, M., Mettinger, K., Gill, G., Evans, T.R., de Bono, J.S. (2011): "A phase I study of the combination of intravenous reovirus type 3 Dearing and gemcitabine in patients with advanced cancer". Clinical Cancer Research.17 (3): 581-8.

MacNeill, A.L., Moldenhauer, T., Doty, R., Mann, T. (2012): Myxoma virus induces apoptosis in cultured feline carcinoma cells. Res. Vet. Sci.,93: 1036-1038.

MacTavish, H., Diallo, J.S., Huang, B., Stanford, M., Le Boeuf, F., De Silva, N., Cox, J., Simmons, J.G., Guimond, T., Falls, T. (2010): Enhancement of vaccinia virus based oncolysis with histone deacetylase inhibitors. PLoS One., 5: 14462.

Mahalingam, D., Goel, S., Coffey, M., Noronha, N., Selvaggi, G., Nawrocki, S., Nuovo, G., Mita, M. (2015): Oncolytic Virus Therapy in Pancreatic Cancer: Clinical Efficacy and Pharmacodynamic: Analysis of reolysin in Combination with Gemcitabine in Patients with Advanced Pancreatic Adenocarcinoma. Ann Oncol., (Suppl 4); 26: 51.

Massari, I., Donnini, A., Argentati, K., Strain, S., Mangoni, A., Gaetano, C. (2002): Age-dependent effects of repeated immunization with a first generation adenovirus vector on the immune response and transgene expression in young and old rats. Exp. Gerontol., 37(6): 823-31.

Mathias, P., Wickham, T., Moore, M., Nemerow, G. (1994): Multiple adenovirus serotypes use alpha v integrins for infection. J. Virol., 68: 6811-6814.

McLaughlin-Drubin, M.E., Munger, K. (2008): Viruses associated with human cancer. Biochim Biophys Acta., 1782: $127-50$.

Mederle, O., Mederle, N., Bocan, E.V., Ceausu, R., Raica, M. (2010): VEGF expression in dog mastocytoma. Rev Med Chir Soc Med Nat Iasi., 114: 185-188.

Melcher, A., Parato, K., Rooney, C.M., Bell, J.C. (2011): Thunder and lightning: immunotherapy and oncolytic viruses collide. Mol. Ther., 19(6): 08-16.

Merlo, D.F., Rossi, L., Pellegrino, C., Ceppi, M., Cardellino, U., Capurro, C., Ratto, A., Sambucco, P.L., Sestito, V., Tanara, G., Bocchini, V. (2008): Cancer incidence in pet dogs: findings of the Animal Tumor Registry of Genoa, Italy. J, Vet. Intern. Med., 22: 976-984.

Millanta, F., Lazzeri, G., Vannozzi, I., Viacava, P., Poli, A. (2002): Correlation of vascular endothelial growth factor expression to overall survival in feline invasive mammary carcinomas. Vet. Pathol., 39: 690-696.

Miller, A.C., and Russell, S.J. (2014): Heterogeneous delivery is a barrier to the translational advancement of oncolytic virotherapy for treating solid tumors. Virus Adaptation and Treatment., 6(1): 11-31.

Minev, B., Kohrt, H., Kilinc, M., Chen, N., Feng, A., Pessian, M., Geissinger, U., Haefner, E., Tsoneva, D., Bozhilov, K., Sagiv-Barfi, I., Zhao, X., Rajesekaran, N. (2014): Combination immunotherapy with oncolytic vaccinia virus and checkpoint inhibitor following local tumor irradiation. J. for Immunotherapy of Cancer., (Suppl 3); 2: 112.

Miyamoto, S., Inoue, H., Nakamura, T., Yamada, M., Sakamoto, C., Urata, Y., Okazaki, T., Marumoto, T., Takahashi, A., Takayama, K., Nakanishi, Y., Shimizu, H., Tani, K. (2012): Coxsackievirus B3 is an oncolytic virus with immunostimulatory properties that is active against lung adenocarcinoma. Cancer Res.,72: 260921.

Moehler, M.H., Zeidler, M., Wilsberg,V., Cornelis, J.J., Woelfel, T. (2005): Parvovirus H-1-induced tumor cell death enhances human immune response in vitro via increased phagocytosis, maturation, and crosspresentation by dendritic cells. Hum. Gene Ther., 16: 996-1005.

Moerdyk-Schauwecker, M., Shah, N.R., Murphy, A.M., Hastie, E., Mukherjee, P., Grdzelishvili, V.Z. (2013): Resistance of pancreatic cancer cells to oncolytic vesicular stomatitis virus: role of type I interferon signaling. Virology., 436(1): 221-34.

Mullen, J.T. and Tanabe, K.K. (2003): Viral oncolysis for malignant liver tumors. Ann Surg Oncol., 10: 596-605.

Nicholas, T.W., Read, S.B., Burrows, F.J., Kruse, C.A. (2003): Suicide gene therapy with Herpes simplex virus thymidine kinase and ganciclovir is enhanced with connexins to improve gap junctions and bystander effects. Histol. Histopathol., 18: 495-507.

Noser, J.A., Mael, A.A., Sakuma, R., Ohmine, S., Marcato, P., Lee, P.W. (2007): The RAS/Raf1/MEK/ERK signaling pathway facilitates VSV-mediated oncolysis: implica tion for the defective interferon response in cancer cells. Mol Ther., 15(8): 1531-6.

Pan, W., Bodempudi, V., Esfandyari, T., Farassati, F. (2009): Utilizing ras signaling pathway to direct selective replication of herpes simplex virus-1. PLoS One., 4(8): 6514.

Paoloni, M., Khanna, C. (2008): Translation of new cancer treatments from pet dogs to humans. Nat. Rev. Cancer., 8: pp147-156.

Parato, K.A., Breitbach, C.J., Le, Boeuf, F. (2012): The oncolytic poxvirus JX-594 selectively replicates in and 
destroys cancer cells driven by genetic pathways commonly activated in cancers. Mol. Ther., 20(4):pp749758.

Park, B.H., Hwang, T., Liu, T.C., et al. (2008): Use of a targeted oncolytic poxvirus, JX-594, in patients with refractory primary or metastatic liver cancer: a phase I trial. Lancet Oncol., 9(6):533-542.

Park, M,S., García-Sastre, A., Cros, J.F., Basler, C.F., Palese, P. (2003): Newcastle disease virus V protein is a determinant of host range restriction. .J Virol.,77: 9522-32.

Patel, M.R., Kratzke, R.A. (2013): Oncolytic virus therapy for cancer: the first wave of translational clinical trials. Transl. Res., 161(4): 355-64.

Patil, S.S., Gentschev, I., Adelfinger, M., Donat, U., Hess, M., Weibel, S., Nolte, I., Frentzen, A., Szalay, A.A. (2012): Virotherapy of canine tumors with oncolytic vaccinia virus GLV-1h109 expressing an anti-VEGF single-chain antibody. PLoS One., 7: 47472.

Patil, S.S., Gentschev, I., Nolte, I., Ogilvie, G., Szalay, A.A. (2012): Oncolytic virotherapy in veterinary medicine: Current status and future prospects for canine patients. J. Trans. Med., 10: 3.

Pecora, A.L., Rizvi, N., Cohen, G.I., Meropol, N.J., Sterman, D., Marshall, J.L., Goldberg, S., Gross, P., O’Neil, J.D., Groene, W.S., Roberts, M.S., Rabin, H., Bamat, M.K., Lorence, R.M. (2002): Phase I trial of intravenous administration of PV701, an oncolytic virus, in patients with advanced solid cancers. J. Clin. Oncol., 20: 2251-66.

Peruzzi, D., Gavazza, A., Mesiti, G., Lubas, G., Scarselli, E., Conforti, A., Bendtsen, C., Ciliberto, G., La Monica, N., Aurisicchio, L. (2010): A vaccine targeting telomerase enhances survival of dogs affected by B-cell lymphoma. Mol. Ther., 18:1559-1567.

Pluhar, G.E., Grogan, P.T., Seiler, C., Goulart, M., Santacruz, K.S., Carlson, C., Chen, W., Olin, M.R., Lowenstein, P.R., Castro, M.G. (2010): Anti-tumor immune response correlates with neurological symptoms in a dog with spontaneous astrocytoma treated by gene and vaccine therapy. Vaccine., 28: 3371-3378.

Power, A.T., Wang, J., Falls T.J., Paterson, J.M., Parato, K.A., Lichty, B.D., Stojdl, D.F., Forsyth, P.A., Atkins, H., Bell, J.C. (2007): Carrier cell-based delivery of an oncolytic virus circumvents antiviral immunity. Mol. Ther., 15: 123-130.

Prestwich, R.J., Errington, F., Diaz, R.M., Pandha, H.S., Harrington, K.J. (2009): The case of oncolytic viruses versus the immune system: Waiting on the judgment of Solomon. Hum. Gene Ther., 20: 1119-1132

Prestwich, R.J., Errington, F., Ilett, E.J. (2012): Tumor infection by oncolytic reovirus primes adaptive antitumor immunity. Clin Cancer Res., 14: 7358-7366.

Prestwich, R.J., Harrington, K.J., Pandha, H.S., Vile, R.G., Melcher, A.A., Errington, F. (2008): Oncolytic viruses: a novel form of immunotherapy. Expert Rev Anticancer Ther., 8(10): 1581-810.

Puzanov, I., Milhem, M.M., Andtbacka, R.H., Minor, D.R., Hamid, O., Li, A., Chou, J., Kaufman, H. (2015): Survival, safety, and response patterns in a phase $1 \mathrm{~b}$ multicenter trial of talimogene laherparepvec (T-VEC) and ipilimumab (ipi) in previously untreated, unresected stage IIIB-IV melanoma. ASCO Meeting Abstracts.,33: 9063.

Puzanov, I., Milhem, M.M., Minor, D., Hamid, O., Li, A., Chen, L., Chastain, M., Gorski, K.S., Anderson, A., Chou, J., Kaufman, H.L., Andtbacka, R.H. (2016): Talimogene Laherparepvec in Combination With Ipilimumab in Previously Untreated, Unresectable Stage IIIB-IV Melanoma. J. Clin. Oncol., 34: 2619-26.

Qiao, J., Wang, H., Kottke, T., White, C., Twigger, K, Diaz, R.M., Thompson, J., Selby, P., de Bono, J., Melcher, A., Pandha, H., Coffey, M., Vile, R., Harrington, K. (2008): Cyclophosphamide facilitates antitumor efficacy against subcutaneous tumors following intravenous delivery of reovirus. Clin Cancer Res., 14: 259-69.

Queiroga, F.L., Raposo, T., Carvalho, M.I., Prada, J., Pires, I. (2011): Canine mammary tumours as a model to study human breast cancer: most recent findings. In Vivo., 25: 455-465.

Rajani, K., Parrish, C., Kottke, T., Thompson, J., Zaidi, S., Ilett, L., Shim, K.G., Diaz, R.M., Pandha, H., Harrington, K., Coffey, M., Melcher, A., Vile, R. (2016): Combination Therapy With Reovirus and Anti-PD1 Blockade Controls Tumor Growth Through Innate and Adaptive Immune Responses. Mol Ther., 24:16674.

Ranki, T., Pesonen, S., Hemminki, A., Partanen, K., Kairemo, K., Alanko, T., Lundin, J., Linder, N., Turkki, R., Ristimäki, A., Jäger, E., Karbach, J., Wahle, C. (2016): Phase I study with ONCOS-102 for the treatment of solid tumors - an evaluation of clinical response and exploratory analyses of immune markers. J. Immuno ther. Cancer., 4: 17.

Ribacka, C. and Hemminki, A. (2006): Virotherapy as an approach against cancer stem cells. Current gene therapy., 8(2): 88-96.

Roberts, M.S., Lorence, R.M., Groene, W.S., Bamat, M.K. (2006): Naturally oncolytic viruses. Curr. Opin. Mol. Ther., 8: 314-321.

Romagnani, C., Della, Chiesa, M., Kohler, S., Moewes, B., Radbruch, A., Moretta, L. (2005): Activation of human NK cells by plasmacytoid dendritic cells and its modulation by CD4+ T helper cells and CD4+ CD25hi T regulatory cells. Eur J. Immunol. 35(8): 2452-8. 
Ruf, B., Berchtold, S., Venturelli, S. (2015): “Combination of the oral histone deacetylase inhibitor resminostat with oncolytic measles vaccine virus as a new option for epi-virotherapeutic treatment of hepatocellular carcinoma," Molecular Therapy Oncolyticsl., 2: 1501.

Russel, S.J., Peng, K-W., Bell, J.C. (2012): Oncolytic virotherapy. Nature Biotechnology., 30: 658-70.

Downs-Canner, S., Guo, Z.S., Ravindranathan, R. (2016): "Phase 1 study of intravenous oncolytic poxvirus (vvDD) in patients with advanced solid cancers, ” Molecular Therapy, 24( 8): 1492-1501.

Samson, A., Bentham, M.J., Scott, K. (2016): "Oncolytic reovirus as a combined antiviral and anti-tumour agent for the treatment of liver cancer," Gut, 1-12.

Senzer, N.N., Kaufman, H.L., Amatruda, T., Nemunaitis, M., Reid, T., Daniels, G., Gonzalez, R., Glaspy, J., Whitman, E., Harrington, K., Goldsweig, H., Marshall, T., Love, C. (2009): Phase II clinical trial of a GMCSF-encoding, second-generation oncolytic herpesvirus in patients with unresectable metastatic melanoma. J. Clin. Oncol., 27: 5763-71.

Seth, P., Wang, Z.G., Pister, A., et al. (2006): Development of oncolytic adenovirus armed with a fusion of soluble transforming growth factor-beta receptor II and human immunoglobulin Fc for breast cancer therapy. Hum. Gene Ther., 17(11): 1152-1160.

Shashkova, E.V., Kuppuswamy, M.N., Wold, W.S., Doronin, K. (2008): Anticancer activity of oncolytic adenovirus vector armed with IFN-alpha and ADP is enhanced by pharmacologically controlled expression of TRAIL. Cancer Gene Ther., 15(2): 61-72.

Siddiqui, F., Li, C.Y., Larue, S.M., Poulson, J.M., Avery, P.R., Pruitt, A.F., Zhang, X., Ullrich, R.L., Thrall, D.E., Dewhirst, M.W. (2007): A phase I trial of hyperthermia-induced interleukin-12 gene therapy in spontaneously arising feline soft tissue sarcomas. 6: Mol. Cancer Ther., 380-389.

Singh, P.K., Doley, J., Kumar, G.R., Sahoo, A.P., Tiwari, A.K. (2012). "Oncolytic viruses \& their specific targeting to tumour cells". The Indian Journal of Medical Research., 136 (4): 571-84.

Sirena D, Lilienfeld B, Eisenhut M. (2004): The human membrane cofactor CD46 is a receptor for species B adenovirus serotype 3. J. Virol., 78(9): 4454-4462.

Smakman, N., van der Bilt, J.D., van den Wollenberg, D.J., Hoeben, R.C., Borel Rinkes, I.H., Kranenburg.O. (2006): Immunosuppression promotes reovirus therapy of colorectal liver metastases. Cancer Gene Ther., 13(8): 815-818.

Smith, B.F., Curiel, D.T., Ternovoi, V.V., Borovjagin, A.V., Baker, H.J., Cox, N., Siegal, G.P. (2006): Administration of a conditionally replicative oncolytic canine adenovirus in normal dogs. Cancer Biother. Radiopharm., 21: 601-606.

Smith, T.T., Roth, J.C., Friedman, G.K., Gillespie, G.Y. (2014): Oncolytic viral therapy: targeting cancer stem cells. Oncolytic virotherapy., 3: 21-33.

Song, K.Y., Wong, J., Gonzalez, L., Sheng, G., Zamarin, D., Fong, Y. (2010): Antitumor efficacy of viral therapy using genetically engineered Newcastle disease virus [NDV(F3aa)-GFP] for peritoneally disseminated gastric cancer. J. Mol. Med (Berl).,Jun., 88(6): 589-596.

Stetson, D.B. and Medzhitov, R. (2006): Type I interferons in host defense. Immunity., 25: 373-381.

Stoermer, K.A. and Morrison, T.E. (2010): Complement and viral pathogenesis. Virology., 411(2): 362-73.

Stojdl, D.F., Lichty, B., Knowles, S., Marius, R., Atkins, H., Sonenberg, N., Bell, J.C. (2000): "Exploiting tumorspecific defects in the interferon pathway with a previously unknown oncolytic virus". Nature Medicine. 6 (7): $821-5$.

Stojdl, D.F., Lichty, B.D., tenOever, B.R., Paterson, J.M., Power, A.T., Knowles, S.. (2003): VSV strains with defects in their ability to shutdown innate immunity are potent systemic anti-cancer agents. Cancer Cell., 4(4): 263-75.

Suter, S.E., Chein, M.B., von Messling, V., Yip, B., Cattaneo, R., Vernau, W., Madewell, B.R., London, C.A. (2005): In vitro canine distemper virus infection of canine lymphoid cells: A prelude to oncolytic therapy for lymphoma. Clin. Cancer Res., 11:1579-1587.

Tanaka, T., Huang, J., Hirai, S. (2006): Carcinoembryonic antigen-targeted selective gene therapy for gastric cancer through FZ33 fiber-modified adenovirus vectors. Clin Cancer Res., 12(12): 3803-3813.

Tang, J., Le, S., Sun, L., Yan, X., Zhang, M. (2010): Copy number abnormalities in sporadic canine colorectal cancers. Genome Res., 20: 341-350.

Tatsuo, H., Ono, N., Tanaka, K., Yanagi, Y. (2000): SLAM (CDw150) is a cellular receptor for measles virus. Nature., 406: 893-97.

Ternovoi, V.V., Le L.P., Belousova N., Smith B.F., Siegal G.P., Curiel D.T. (2005): Productive replication of human adenovirus type 5 in canine cells. J. Virol., 79: 1308-1311.

Thorne, S.H. and Contag, C.H. (2008): Integrating the biological characteristics of oncolytic viruses and immune cells can optimize therapeutic benefits of cell-based delivery. Gene Ther.,15: 753-58..

Thorne, S.H., Hwang, T.H., Kirn, D.H. (2005): Vaccinia virus and oncolytic virotherapy of cancer. Curr. Opin. Mol. Ther., 7: 359-365. 
Thorne, S.H., Hwang, T.H., O’Gorman, W.E. (2007): Rational strain selection and engineering creates a broadspectrum, systemically effective oncolytic poxvirus, JX-963. J. Clin. Invest., 117: 3350-3358.

Toda, M., Rabkin, S.D., Kojima, H., Martuza, R.L. (1999): Herpes simplex virus as an in situcancer vaccine for the induction of specific anti-tumor immunity. Hum Gene Ther.,10: 385-93.

Urbasic, A.S., Hynes, S., Somrak, A., Contakos, S., Rahman, M.M., Liu, J., MacNeill, A.L. (2012): Oncolysis of canine tumor cells by myxoma virus lacking the serp2 gene. Am. J. Vet. Res.,73: 1252-1261.

Vacchelli, E., Eggermont, A., Sautes-Fridman, C., Galon, J., Zitvogel, L., Kroemer, G. (2013): Trial watch: oncolytic viruses for cancer therapy. Oncoimmunology., 2(6): 4612.

Vaha-Koskela, M.J., Heikkila, J.E., Hinkkanen, A.E. (2007): Oncolytic viruses in cancer therapy. Cancer Lett ., 254(2): 178-216

Van den Hengel, S.K., Balvers, R.K., Dautzenberg, I.J.C. (2013): Heterogeneous reovirus susceptibility in human glioblastoma stem-like cell cultures. Cancer Gene Ther., 20(9): 507-513.

Verheije, M.H. and Rottier, P.J. (2012): Retargeting of viruses to generate oncolytic agents. Adv Virol., 79: 8526.

Vitale, I., Galluzzi, L., Castedo, M., Kroemer, G. (2011): Mitotic catastrophe: a mechanism for avoiding genomic instability. Nat. Rev. Mol. Cell. Biol., 12(6): 385-92.

Wold, W.S.M., and K. Toth, K. (2013): “Adenovirus vectors for gene therapy, vaccination and cancer gene therapy," Current Gene Therapy, vol. 13 (6): 421-433.

Wakimoto, H., Johnson, P.R., Knipe, D.M., Chiocca, E.A. (2003): Effects of innate immunity on herpes simplex virus and its ability to kill tumor cells. Gene Ther., 10: 983-90.

Wennier, S.T., Liu, J., McFadden, G. (2011): Bugs and Drugs: Oncolytic Virotherapy in Combination with Chemotherapy. Curr. Pharm/Biotechnol. Volume and page?

Westberg, S., Sadeghi, A., Svensson, E., Segall, T., Dimopoulou, M., Korsgren, O., Hemminki, A., Loskog, A.S., Totterman, T.H., von Euler, H. (2013): Treatment efficacy and immune stimulation by AdCD40L gene therapy of spontaneous canine malignant melanoma. J. Immuno Ther., 36: 350-358.

Winkler, F., Kozin, S.V., Tong, R.T., Chae. S.S., Booth, M.F. (2004): Kinetics of vascular normalization by VEGFR2 blockade governs brain tumor response to radiation: Role of oxygenation, angiopoietin-1, and matrix metalloproteinases. Cancer Cell.,6: 553-563.

Wohlfahrt, M.E., Beard, B.C., Lieber, A., Kiem, H.P. (2007): A capsid-modified, conditionally replicating oncolytic adenovirus vector expressing TRAIL leads to enhanced cancer cell killing in human glioblastoma models. Cancer Res., 67(18): 8783-90.

Woller, N., Gürlevik, E., Fleischmann-Mundt, B., Schumacher, A., Knocke, S., Kloos, A.M., Saborowski, M., Geffers, R., Manns, M.P., Wirth, T.C., Kubicka, S., Kühnel, F. (2015): Viral Infection of Tumors Overcomes Resistance to PD-1-immunotherapy by Broadening Neoantigenome-directed T-cell Responses. Mol. Ther., 23: $1630-40$.

Woller, N., Gürlevik, E., Ureche, C.I., Schumacher, A., Kühnel. F. (2014): Oncolytic viruses as anticancer vaccines. Harnessing Oncolytic Virus-mediated Antitumor Immunity., 4(188): 1-13.

Workenhe, S.T., Mossman, K.L. (2014): Oncolytic virotherapy and immunogenic cancer cell death: sharpening the sword for improved cancer treatment strategies. Molecular Therapy., 22(2): 251-256.

Workenhe, S.T., Verschoor, M.L., Mossman, K.L. (2015): The role of oncolytic virus immunotherapies to subvertcancer immune evasion. Future Oncology., 11(4): 675-689.

Zamarin, D., Holmgaard, R.B., Subudhi, S.K., Park, J.S., Mansour, M., Palese, P., Merghoub, T., Wolchok, J.D., Allison, J.P. (2014): Localized Oncolytic Virotherapy Overcomes Systemic Tumor Resistance to Immune Checkpoint Blockade Immunotherapy. Sci. Transl. Med., 6: 226-32.

Zamarin, D. and Palese, P. (2012): Oncolytic Newcastle disease virus for cancer therapy: old challenges and new directions. Future Microbiol., 7(3): 347-367.

Zamarin, D., Martínez-Sobrido, L., Kelly, K., Mansour, M., Sheng, G., Vigil, A. (2009): Enhancement of oncolytic properties of recombinant Newcastle disease virus through antagonis of cellular innate immune responses. Mol. Ther., 17(4): 697-706.

Zhang, J., Chen, X., Kent M.S., Rodriguez, C.O. (2007): Establishment of a dog model for the p53 family pathway and identification of a novel isoform of p21 cyclin-dependent kinase inhibitor. Mol. Cancer. Res., 7: 67-78.

Zhang, S.C., Wang, W.L., Cai, W.S., Jiang, K.L., Yuan, Z.W. (2012): Engineered measles virus Edmonston strain used as a novel oncolytic viral system against human hepatoblastoma. BMC Cancer., 12: 427.

Zhao, L., Dong, A., Gu, J., Liu, Z., Zhang, Y., Zhang, W. (2006): The antitumor activity of TRAIL and IL-24 with replicating oncolytic adenovirus in colorectal cancer. Cancer Gene Ther., 13(11): 1011-22.

Zimmermann, M., Armeanu, S., Smirnow, I. (2009): Human precision-cut liver tumor slices as a tumor patientindividual predictive test system for oncolytic measles vaccine viruses. Int. J. Oncol., 34(5): 1247-1256.

Zou, W. (2005): Immunosuppressive networks in the tumour environment and their therapeutic relevance. Nat. Rev. Cancer., 5(4): 263-274. 